\title{
Reflejos de la vida intelectual en la musivaria romana
}

\author{
Guadalupe López Monteagudo * y María Pilar San Nicolás Pedraz **
}

Los mosaicos figurados constituyen una valiosa fuente de información sobre la sociedad de época romana, que viene a completar los datos aportados por las fuentes epigráficas y literarias. Muchos de ellos confirman el ambiente general que dan a conocer Sidonio Apolinar o San Agustín cuando describen las actividades de los ricos propietarios de las villae de Galia y Africa del Norte, de los que dicen que vivían en mansiones espléndidas y que pasaban el tiempo dedicados al juego, a la caza, a los banquetes y a la administración de sus bienes ${ }^{1}$. Sin embargo, una parte considerable de los pavimentos figurados muestra escenas sacadas de la mitología, reflejando el grado de coriocimiento que los domini tenían de la cultura clásica no solo en su forma sino sobre todo en su contenido de caracter alegórico.

Entre los temas de la vida intelectual que aparecen en la musivaria romana nos interesan los relacionados con las variadas ramas de la cultura, mediante la representación de literatos, poetas, oradores, historiadores, etc., destacando entre todos ellos Homero, el clásico por excelencia, patrón de la cultura literaria; y de aquellos relacionados con las ciencias empíricas y experimentales, como pueden ser los filósofos, astrónomos, matemáticos, físicos, etc., presididos por Sócrates, patrono de la cultura filosófica.

En estas representaciones hay que distinguir varios tipos, según se trate de la mera representación de los bustos de los sabios, acompañados generalmente por la inscripción con su nombre; de figuras individuales de

* $\mathrm{CSIC}$

** UNED

P. Romanello, Riflessi di vita locale nei mosaici africani, CMGR I, 1969, 275 y ss.; D. PARRISH, Two Mosaics from Roman Tunisia: an African Variation of the Season Theme, AJA 83, 1979,279 y ss. 
sabios, solos o en compañía de las musas, con algún atributo o instrumento referente a su especialidad científica, identificados o no por nombre; y de grupos de sabios discutiendo sobre un tema científico o filosófico, con o sin letreros identificativos. Las inscripciones que acompañan a algunas de estas representaciones, bien sea en forma de rótulos con los nombres o de textos literarios, permiten su segura identificación, ya que los rasgos fisonómicos no siempre responden a la identidad de los retratados, pudiéndose hablar más de retratos genéricos o idealizados que de individuos concretos ? ${ }^{2}$ La representación de los distintos tipos iconográficos abarca una amplia cronología, que va desde comienzos del siglo I d.C. hasta época bizantina, con una mayor preponderancia en el siglo III. De igual forma, su distribución geográfica dentro del imperio romano difiere de unas áreas a otras, variando los distintos tipos iconográficos según los lugares.

El tema de los siete sabios, personajes históricos que vivieron a comienzos del siglo VI a.C., especializados en las diversas ramas del saber tanto técnico, como artístico y político, y paradigmas no solo de la sabiduría (sophía) sino también de la sensatez (sophrosyné), gozó de una gran aceptación desde el periodo helenístico hasta el final de la antigüedad, siendo un tema muy representado en los relieves, sarcófagos y en la musivaria romana, siguiendo modelos pictóricos ${ }^{3}$. El grupo canónico de los siete sabios griegos, citado por primera vez por Platón (Protag. 343 A), se encuentra en dos mosaicos de fecha temprana procedentes de la Península itálica: Torre Annunziata en el Museo Nazionale de Nápoles, fechado en el siglo I d.C., y Sarsina, del siglo II d.C., donde los sabios o filósofos reunidos en torno a la esfera y en presencia de un reloj solar discuten sobre el tiempo.

El mosaico de Torre Annunziata (Fig. 1), que se conserva en el Museo Nazionale de Nápoles y se fecha a comienzos del siglo I d.C., fué hallado en 1897 en las excavaciones realizadas en una casa de campo de las proximidades de Pompeya ${ }^{4}$. En el emblema de forma cuadrada se ha representado

2Los antecedentes del tema iconográfico del «filósofo» (personaje que implica una actividad intelectual) aparecen en el arte griego de finales del siglo $\mathrm{V}$ a.C. conectados a la aparición del retrato fisonómico y como consecuencia de la eciosión intelectual determinada por el pensamiento sofístico, queriendo representar en general a la clase intelectual de! mundo antiguo más que al idividuo concreto, cf. A. Giuliano, Filosofi, EAA 3, Roma 1960, 681.

3 K. GAISER, Das Philosophenmosaik in Neapel, Heidelberg 1980. Sobre la popularidad de los siete sabios en época romana cf. Plutarco, conu.spt.sapient. y Ausonio, lud.sept.sapient.

4 A. Sogliano, L'Accademia di Platone rappresentata en un mosaico pompeiano, Monumenti Antichi VIII, 1898, 389-416; S.REINACH, RPGR, Paris 1922, 261; F. DReXel, Das 


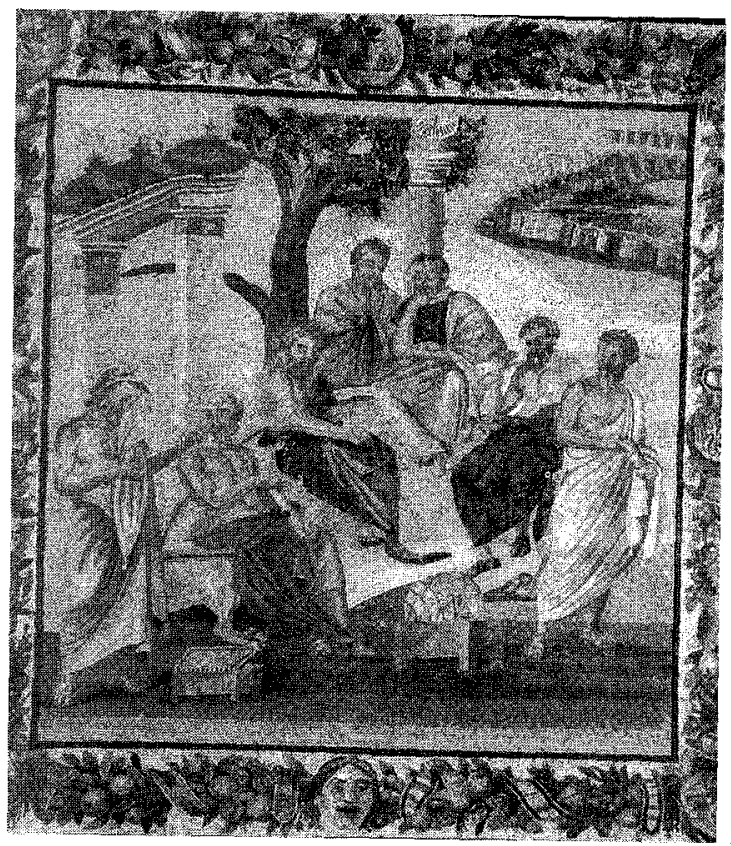

Figura 1. Mosaico de Torre Annunziata.

a los siete sabios en un edificio indicado sumariamente por dos columnas y una tercera separada por un árbol en donde hay un reloj del sol. Al fondo a la derecha se representa el Acrocorinto, según O.J. Brendel o la acrópolis de Atenas, según A. Sogliano. De los siete personajes cuatro están sentados en un banco en forma de exedra con patas de león y los tres restantes se hallan en pie, uno a cada lado y el tercero detrás ${ }^{5}$. Todos llevan barba y se cubren con himation, excepto el quinto que va vestido con chiton, dejando al descubierto el brazo derecho, menos el cuarto personaje

\footnotetext{
Philosophenmosaik von Torre Annunziata, RM 27, 1912, 234-240; G.W. ELDERKIN, Two Mosaics representing the Seven Wise Men, AJA XXXIX, 1935, 92 y ss.; Id., Mosaiks of the Seven Sages, $R M$ 52, 1937, 223 y ss.; O. J. BRENDEL, Symbolik der Kügel, $R M$ 51, 1936, 1 y ss.; Id. Symbolism of the Sphere, EPRO, Leiden 1977; K. SCHEFFOLD, Die Bildnisse der antike Dichter, Redner und Denken, Bâle 1943; H. vON HEINTZE, Zu den Bildnissen der Sieben Weisen, Festchrift F. Brommer, Mainz 1977, 166, Taf. 46,1; K. GAISER, Das Philosophenmosaik in Neapel, Heidelberg 1980.

5 Esta clase de asiento, típicamente helenístico, se documenta en el relieve funerario del rodio Hieronymos, techado en el siglo III a.C. (vid. infra), cf. P.M. Fraser, Rhodian Funerary Monuments, Oxford 1977, 34-36, pl. 97; E. PFUHL - H. MöBIUs, Die ostgriechischen Grabrelief, Mainz 1979, II, 501; A. SCHOLL, Polytalanta Mnemeia. Zur litterarischen und monumentalen Uberlieferung aufwendiger Grabmäler im spätantiken Athen, Jdl 109, 1994, 247-249, Abb. 7.
} 
que oculta los brazos y las manos debajo de su vestimenta. Tres de ellos, el segundo, el sexto y el séptimo, sostienen un rollo en la mano, atributo de los filósofos, que con toda seguridad han debido sacar de una caja entreabierta que se encuentra en el suelo, no lejos de la esfera que, colocada en el interior de una especie de caja cuadrada, constituye el centro de atención del grupo.

Tradicionalmente y a falta de incripciones identificatorias se ha supuesto, con algunas variantes, que los personajes que intervienen en la escena son los siete sabios y así se han identificado, de izquierda a derecha a Períandro de pie y con diadema; Tales, señalando la esfera con un bastón; Bías y Quilón sentados; y Pítaco que aparece en pie y de frente. F. Drexel identifica a los dos primeros como Hesíodo y Homero, Protágoras el cuarto, Prodikos (?) el quinto, mientras que Gorgias sería el personaje que señala la esfera por ser este personaje el que sostiene el globo en el relieve funerario de Isócrates, e Isócrates el último. Por su parte K. Gaiser trata de identificar la escena, con justificados argumentos, como una representación de la Academia de Platón, ya que según él los personajes que no llevan nombre no representan a los siete sabios, sino a los filósofos de la Academia. De esta forma, el primer personaje en pie situado a la izquierda, el "orador", que sujeta su cabello con una banda igual que el "orador" del mosaico de Sarsina (vid. infra), podría identificarse con Herakleides Pontikos del que se tienen noticias en Diógenes Laercio (V 86) ${ }^{6}$. El personaje calvo sentado que le sigue, con rollo en la mano, podría ser Speusipp. El hombre sentado delante de un árbol que con la vara apunta a la esfera, hacia la que también dirige su mirada, es Platón. Más problemática resulta la identificación del personaje en pie situado detrás con las manos ocultas bajo el manto, ya que de esta forma describe Demóstenes $(19,251)$ una estatua de Solón, pero también podría tratarse de un visitante o quizás de Eratóstenes de Kyrene, en opinión de K. Gaiser. Eudoxos de Knidos es el personaje sentado en el centro de la exedra, delante de la columna que sostiene el reloj de sol; lleva chiton debajo del himation y apoya la barbilla sobre su mano derecha; su situación, distanciada y al mismo tiempo central, y su vestimenta le colocan en una posición intermedia entre el resto de los componentes de la exedra y el visitante de detrás. El último personaje sentado, llevando un rollo en la mano y con la expresión un poco perdida como en actitud meditabunda, es

- Al parecer se trata de un tocado oriental, la «mitra», sin paralelos en las representaciones de filósofos griegos. Solamente Pitágoras lleva un turbante en contorniatus y en una herma del Museo Capitolino, cf. K. GaIser, Das Philosophenmosaik in Neapel, Heidelberg 1980, 51 y ss. 
Xenócrates. Finalmente, K. Gaiser identifica como Aristóteles al personaje del extremo derecho, en pie y medio vuelto de espaldas al grupo, sostiendo un rollo y que dirige la mirada escéptica hacia el orador.

La escena tiene lugar en un escenario arquitectónico formado por un arquitrabe sobre el que se encuentran cuatro vasijas (anathemata), número que, en opinión de K. Gaiser, tal vez hay que poner en relación con las cuatro Musas de las Matemáticas: Aritmética, Geometría, Astronomía y Teoría de la Música, o también con el teorema de Pitágoras (Tetraktys) que tenía un gran significado en la Escuela de Platón; aunque igualmente podrían aludir a los cuartos del sol o del año por la presencia conjunta del reloj solar y de la esfera celeste. Al fondo se divisa una colina con unos edificios, escaleras y muralla, que parece ser una representación idealizada de la Acrópolis de Atenas con sus componentes característicos: colina, Partenón, escaleras de la vía sacra y quizás el teatro de Dionisos.

Del análisis exhaustivo de la escena representada deduce K. Gaiser que se trata de la academia de Platón. A ello inducen la personalidad de los retratados con los rollos en la mano, atributo de los filósofos y no de los sabios; la presencia de la caja como «biblioteca» y del globo celeste, del que había un modelo para los estudios astronómicos en la Academia de Platón; el banco en exedra con patas de león, tal como describen algunos autores los lugares de enseñanza (Diog. Laert. IV 19; Cic. de fin. V $2,4)$; la puerta con las cuatro vasijas; el árbol, plátano u olmo, que según las fuentes litararias se erigía en la Academia; y en fin, el reloj de sol, requisito de toda escuela filosófica y también de la academia platónica (Plat. Athen. IV $174 \mathrm{c}-\mathrm{d})$.

En el panel cuadrado hallado en Sarsina (Fig. 2), fechado en el siglo II d.C., se representa una escena muy semejante a la del mosaico de Torre Annunziata, con siete personajes reunidos en torno a la esfera también a manera de simposion ${ }^{7}$. Aunque ambos proceden de un mismo original helenístico, sin embargo existen diferencias en el tratamiento de las imágenes y del fondo del cuadro. El mosaico de Sarsina es mucho más estático y estilizado, no existiendo comunicación entre los personajes como ocurría en la escena de Torre Annunziata, sino que todos se hallan en actitud pensativa mirando a la esfera que se encuentra colocada sobre un

\footnotetext{
S. ReInach, RPGR, Paris 1922, p. 261; G.A. Mansuelli, Mosaici Sarsinali, Studi Romagnoli (Faenza) 5, 1954, 151-183; W. HELBIG, Führer durch die öfentlichen Sammlungen Klassischer Altertümer in Rom, Band IV, Tübingen 1972, 4, n² 3.350, pp. 327-328; K. GaISER, Das Philosophenmosaik in Neapel, Heidelberg 1980, 13-14. Sobre las restauraciones realizadas en este panel cf. K. Parlasca, en W. HeLBIG, Führer IV, 4, nº 3350, Tübingen 1972, 327-328.
} 


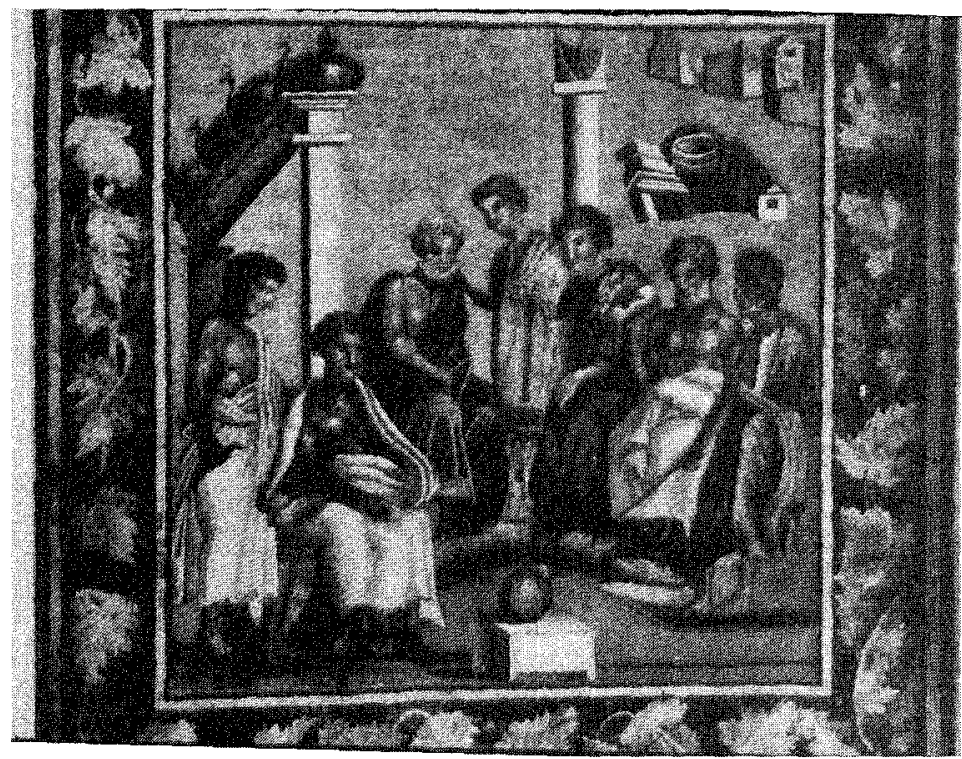

Figura 2. Mosaico de Sarsina.

soporte de forma cuadrangular en el centro de la composición. Solamente el primer personaje de la derecha señala con un puntero a la esfera mientras dirige su mirada al grupo de los reunidos. Estos se encuentran sentados, a excepción del primero y el cuarto que se hallan en pie, en un banco en forma de exedra con patas de león; van vestidos con himation y ninguno de ellos porta el rollo característico de los filósofos. El primer personaje de la izquierda sujeta los cabellos con una banda y lleva una serpiente en la mano derecha, por lo que K. Gaiser piensa que podría identificarse con Herakleides Pontikos, eminente miembro de la Academia en tiempos de Platón y de Speusipp, mientras que Ch. Picard se inclina por Demetrios de Phalere que también lleva una diadema en el Serapeion de Menfis ${ }^{8}$.

La escena se desarrolla, como la de Torre Annunziata, en un ambiente arquitectónico indicado igualmente por un arquitrabe sobre el que se encuentran cuatro vasijas esféricas con prótomos de grifos y una columna que sostiene un reloj de sol. Falta sin embargo el árbol y la caja de los rollos, la «bilioteca», dos de los elementos necesarios para identificar la

8 Cf. J.-PH. Laver - CH. Picard, Les statues ptolemaíques du Serapeion de Memphis, Paris 1955,38 y ss. 
escena representada con la academia de Platón. Al fondo se divisa una muralla y delante de ella una serie de edificios entre los que parece destacar un anfiteatro. Según K. Gaiser, la escena reflejaría también una representación de la academia de Platón y ambos mosaicos derivarían de un mismo original helenístico de hacia el 200 a.C. ${ }^{9}$.

Por nuestra parte pensamos que las escenas figuradas en los mosaicos itálicos de Torre Annunziata y Sarsina no responden a situaciones realistas, sino que se trata de representaciones idealizadas de una conversación filosófica. La misma ausencia de inscripciones identificatorias refuerza esta hipótesis según la cual existe un buscado propósito de representar no a unos sabios concretos o a una academia determinada, sino al mundo académico en general ocupado en tareas científicas, ya sean de carácter empírico o experimental. De esta forma, las copias romanas de un original helenístico constituían un reflejo de la realidad académica del momento.

Si se cree a Plutarco, los temas abordados por los Siete Sabios eran de muy variada naturaleza: máximas sobre el gobierno de los Estados y de las casas, funcionamiento de los astros, adivinanzas sobre lo que es más bello, más sabio, etc.; como señala J. Defradas, en Plutarco el objeto general de la discusión entre los Sabios es mostrar la importancia del dominio del alma sobre el cuerpo y el control de las pasiones como forma de alcanzar la sabiduría ${ }^{10}$. Para $O$. Brendel el tema de la conversación parece ser la esfera, al que también aluden algunas fuentes antiguas (Plut.Sept.Sap.Conu. 9,153 C; Diog. Lart. Tales 35; Ps. Platon, carta 2, 312 D; carta 13, 363 D I; Arist. Meteor. I 8,346 a 31-35; de anima I 1,403 a 13; Timaios $40 \mathrm{D}$; Cicer. de republica I 22, habla del globo celeste de Eudoxos; Philebos 68 A). Si se admite la identificación del primer personaje de la izquierda, el "orador", como Herakleides Pontikos, hay que suponer que el tema de conversación gira en torno a la obra de este autor, cuyo título «Peri ton ouranon» (Sobre los fenómenos del cielo) se conoce por Diogenes Laercio ( $\mathrm{V}$ 87); y aún más, si el cuarto personaje es Eratóstenes, como piensa K. Gaiser, está claro que la discusión está centrada en la astronomía, aunque en opinión de este autor sería de una forma simbólica ya que aquí la esfera no se ha representado en su sentido astronómico, sino como símbolo de la especulación religioso-filosófi$\mathrm{ca}$, lo que unido a la presencia del reloj de sol induciría a pensar en el

K. GaISER, Das Philosophenmosaik in Neapel, Heidelberg 1980, 8, 13, 60 y ss., 92-96, 105.

10 Plutarco, Le Banquet des Sept Sages. Texte, traduction avec une introduction et de notes, por J. Defradas, Paris 1954, 15, 84-85. 
tiempo, es decir, en la relación de movimiento entre el cielo y la tierra, como tema de la conversación de unos filósofos que, aunque no fueran astrónomos, también tenían conocimientos astronómicos ${ }^{11}$.

La esfera armilar, que aparece en ambos pavimentos, también está representada junto a los sabios en los mosaicos de Mérida, Brading y Trier ( vid. infra), constituyendo el tema decorativo de un mosaico helenístico de Solunto de mediados del siglo II a.C. procedente del ambiente situado al E. del vestíbulo de la Casa de Leda, datado a mediados del siglo II a.C.; en él se ha figurado la esfera armilar y las cabezas de los vientos en las esquinas ${ }^{12}$. Otras representaciones de la esfera armilar se encuentran en pinturas de Stabia, de mediados del siglo I d.C., y de Vienne ${ }^{13}$ La invención de la esfera armilar se atribuye a Hipparco en el siglo II a.C. (Claud. Ptol. geogr. VII 6, I 22-23), que perfeccionó el sistema inventado por Anaximandro y Eudoxio añadiendo a la esfera los veinticuatro meridianos horarios que convergen en los polos. Según Estrabón $(1,21 \mathrm{C} \mathrm{13})$ el conocimiento de los círculos de la esfera celeste era universal, de forma que todo el mundo había visto en su vida la esfera celeste ya que el estudio de los círculos variables, el horizonte y los círculos árticos eran objeto de cursos elementales de matemáticas ${ }^{14}$.

El sistema ptolemáico, integrado por el sol, los planetas, el globo terrestre y el cielo estrellado, se representaba en un mosaico perdido que, según S. Reinach, había pertenecido de la colección del escultor Albaccini. Se trata de una representación planetaria y esférica de la tierra en el centro del sistema, ya que se ha figurado el sol, los planetas mediante esvásticas, el globo terrestre en el centro de una semi-esfera y el cielo estrellado ${ }^{15}$. A Tales se atribuye la invención de la primera esfera celeste, la esfera llena que llevaría en su superficie los cinco círculos que dividen el cielo (Cic. Rep. I 14,22), siendo Anaximandro quien precisó los solsticios y los equinocios, calculó la inclinación de la elíptica dibujando el primer mapa de la tierra e introdujo el reloj de sol en Grecia (Diog. Laert. II 1). Las

11 K. Galser, Das Philosophenmosaik in Neapel, Heidelberg 1980, 37-50, 68-94.

12 M.DE VOS, Pitture e mosaico a Solunto, BullAntBesch. 50, 1975, 195-224, Tav. 11-12, con referencias literarias y arqueológicas.

13 M. BORDA, La pittura romana, Milano 1958; A. BLANCHET, Etude sur la décoration des édifices de la Gaule Romaine, Paris 1913, 29. Para el estudio de la esfera armilar y de otros paralelos, cf. K. GaISER, Das Philosophenmosaik in Neapel, Heidelberg 1980, 40.

14 Cf. P. ARnaud, L'image du globe dans le monde romain, MEFRA 96/1, 1984, 53 y ss.

15 G.A. Guattani, Monumenti antichi inediti, Roma 1786, 51-52, pl. 1-2; S. REINACH, RPGR, París 1922, 25,3; A. SCHLACHTER - F. GISINGER, Der Globus, seine Entstehung und Verwendung in der Antike, Leipzig-Berlin 1927, 57, Abb. 25. 
imágenes simbólicas de las constelaciones percibidas desde el exterior sobre la superficie de la esfera se deben a Eudoxio. Más tarde Hipparco perfeccionó el sistema añadiendo los veinticuatro meridianos horarios que convergen en los polos ${ }^{16}$.

Una representación muy similar de la esfera dentro de una caja se documenta en una pintura pompeyana de la Casa del Criptopórtico (Fig. 3), así como en un mosaico de Cos de mediados del siglo II d.C. y en otro de Baccano datado a comienzos del siglo III, donde la musa de la astronomía Urania lleva una esfera dentro de una caja ${ }^{17}$.

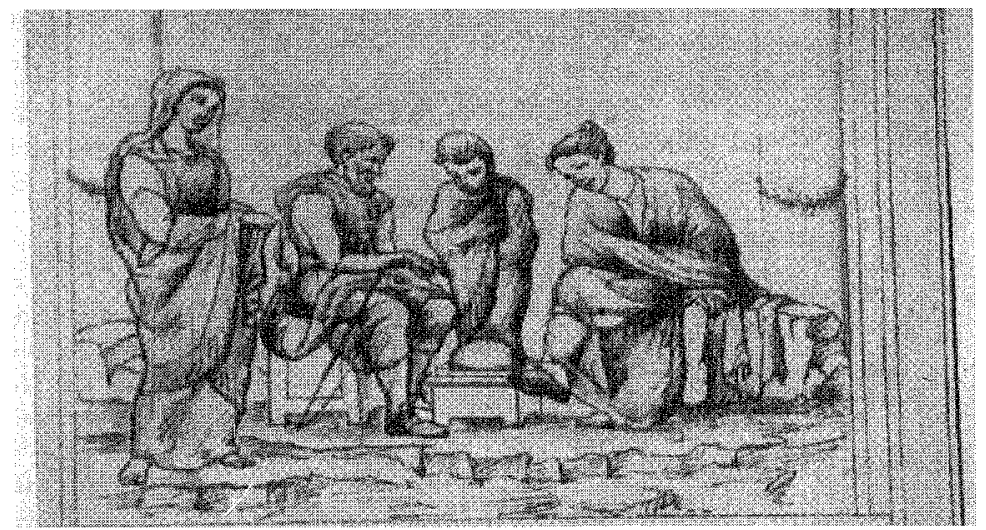

Figura 3. Pintura de la Casa del Criptopórtico en Pompeya.

Entre los pavimentos de la villa de Brading destaca un panel de comienzos del siglo III, en donde está representada la figura de un sabio señalando con un puntero a una esfera colocada sobre un trípode delante de él (Fig. 4); está sentado y va vestido como la figura del sabio sosteniendo un reloj de sol transportable del mosaico de Trier, identificado por $\mathrm{K}$. Parlasca como Anaximandro ( vid. infra); a la derecha y en un segundo plano se ha colocado un reloj de sol sobre una columna; a la izquierda del sabio y sobre el suelo se ve un gran recipiente esférico lleno de líquido.

\footnotetext{
16 Cf. P. ARnAUD, L'image du globe dans le monde romain, MEFRA 96/1, 1984, 53 y ss. En un grafito de Pompeya, hoy perdido, se decía que el cielo está dividido en siete zonas que se juntan en los polos: continuere caelum septem caeli zonae, quae polis iunt(ae sunt), cf. K. GAISER, Das Philosophenmosaik in Neapel, Heidelberg 1980, 118.

17 M. DELLA CORTE, L'educazione di Alessandro Magno nell'enciclopedia aristotelica in un trittico megalografico di Pompei del 11 stile, RM 57-58, 1942-1943, 31 y ss.; E. THEOPHILIDOU, Die Musenmosaiken der römischen Kaiserzeit, TZ 47, 1984, 249-250, 267-270, Abb. 4.
} 


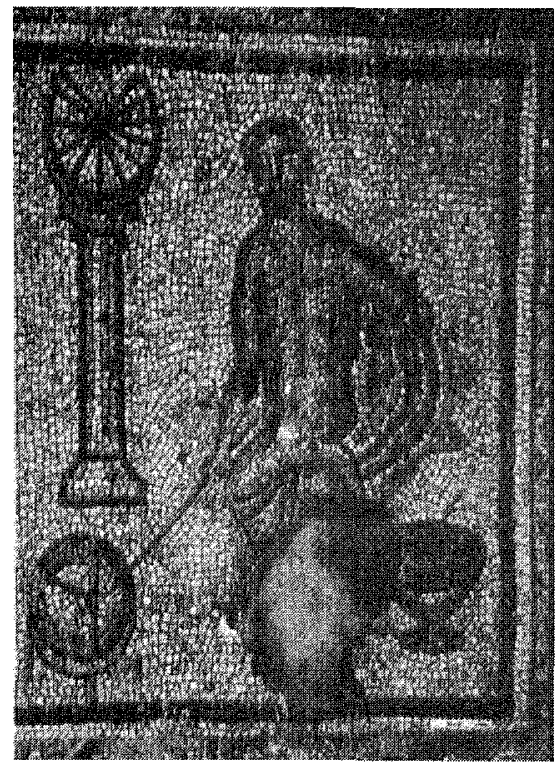

Figura 4. Mosaico de Brading.

Podría tratarse de Tales de Mileto, geómetra y astrónomo, fundador de la filosofía cosmológica, según Aristóteles, cuyo principio se basaba en que el agua era la fuente de todas las cosas, y que en el serapeion de Menfis y en el fresco de Ostia aparece identificado por su nombre como el personaje que señala con una vara algo en el suelo; de su sucesor Anaximandro de Mileto quien, según Diógenes Laercio (II 1), precisó los solsticios y los equinocios, calculó la inclinación de la elíptica dibujando el primer mapa de la tierra e introdujo el reloj de sol en Grecia; o del propio Arquímedes, cuyos estudios sobre mecánica e hidrostática cristalizaron en el famoso principio que lleva su nombre y en cuya tumba se esculpieron, siguiendo su deseo, una esfera y un cilindro (Cic. Tusc. V 64 ss.); de Arato, astrónomo autor de los Phaenomena, identificado por inscripción con su nombre en el mosaico de Monnus, de Trier, en compañía de la musa Urania y apuntando igualmente a la esfera (vid. infra); o, como sugiere R. Ling, de Gorgias que en la tumba de Isócrates en Atenas aparece con un globo ${ }^{18}$.

18 O. J. Brendel, Symbolism of the Sphere, EPRO, Leiden 1977, 14-15, Pl. X.; R. LING, Brading, Brantingham and York: a New Look at Stone Fourth-Century Mosaics, Britannia XXII, 1991, 148-150, pl. XVII A. 
Otras composiciones donde la esfera constituye el centro de atención son el relieve de las Parcas de la colección Dresnai (Fig. 5), datado a mediados del siglo II a.C.; pintura pompeyana del peristilo de la Casa de los Vetii (Fig. 6), donde la musa de la astronomía Urania señala con un puntero a la esfera situada sobre un plinto en el suelo; y la citada pintura pompeyana de la Casa del Criptopórtico que muestra a tres personajes, dos mujeres y un filósofo alrededor de la esfera ${ }^{19}$.

En varias ocasiones es Urania, diosa celeste, musa de la astronomía y del universo en la filosofía estoica (Platón, Phaedr. 259 D; Anthol. gr. IX 505; Corn. O. I. XIV 17,4), la que lleva los ingenios técnicos de la ciencia de la que es protectora, la esfera sobre todo y en menor medida la caja y el radius o compás. Con la esfera, que es su atributo característico, se representa a Urania en pavimentos de Elis, Cos I, Esparta, Baccano, Trier, Arróniz, Mérida, Moncada, Hippona II, EI Djem I, II, IV y V, Lemta, Sfax. Llevando la esfera dentro de una caja aparece en un mosaico de Cos II de mediados del siglo II y en otro de Baccano datado a comienzos del siglo III. Más rara es la representación del radius o compás que solo se documenta en los mosaicos de Lemta, El Djem V, Sfax y Arróniz (Fig. 7) ${ }^{20}$.

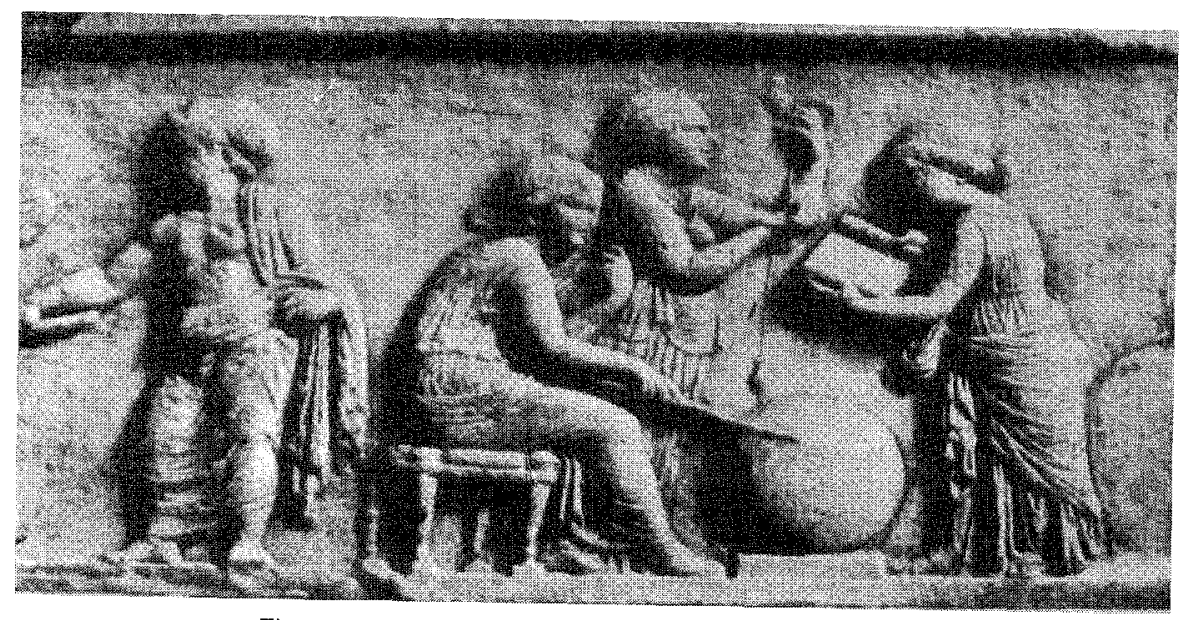

Figura 5. Relieve de las Parcas. Colección Dresnai.

19 Cf. M. DELla CORTE, L'educazione di Alessandro Magno nell'enciclopedia aristotelica in un trittico megalografico di Pompei del II stile, $R M$ 57-58, 1942-1943, 31 y ss.; O. J. BRENDEL, Symbolism of the Sphere, EPRO, Leiden 1977, pl. IX y XXIII.

20 Cf. E. THEOPHILIDOU, Die Musenmosaiken der römischen Kaiserzeit, TZ 47, 1984, 239 y ss. 


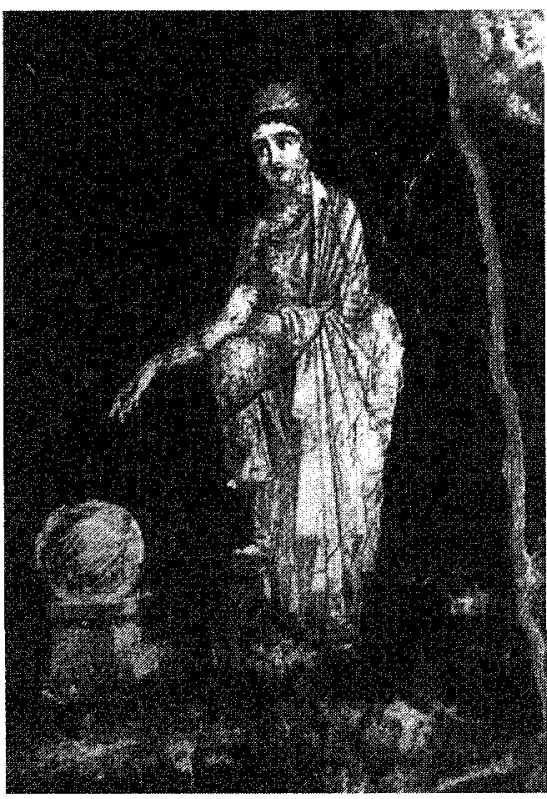

Figura 6. Pintura de la Casa de los Vetii en Pompeya.

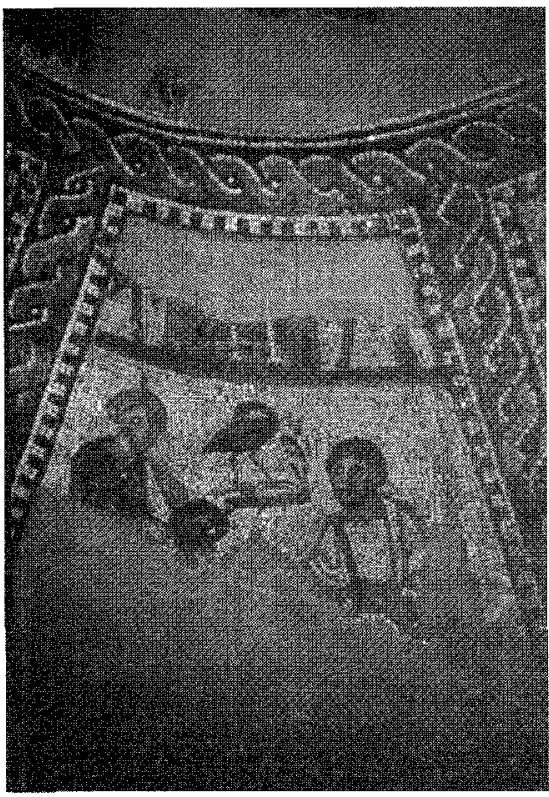

Figura 7. Mosaico de Arróniz. Urania. (Foto G. López Monteagudo).

El reloj de forma cóncava pertenece al tipo de los relojes de mármol que se conservan en el Museo Vaticano (Fig. 8) ${ }^{21}$ y en el Nazionale de las Termas de Roma. Representaciones del reloj de sol junto a los sabios se documentan, además de en Torre Annunziata, Sarsina y Brading, en el pavimento de Trier (Fig. 9). En este último, conservado en el Rheinisches Landesmuseum, se representa una figura masculina de edad madura, con barba y cabello de color blanco, dirigiendo su mirada hacia otro personaje que no aparece en la escena; está sentada en la típica cathedra y cubre los hombros con el pallium; en la mano izquierda sostiene un reloj de sol transportable, mientras que con la derecha sujeta una de las agujas. El mismo tipo de asiento se documenta en otros dos mosaicos procedentes de Trier, el de los «literatos» y el de Monnus, así como en los de Sfax, Autun, Sousse y Palermo (vid infra), siendo utilizado tanto por los sabios

21 Una clasificación de los diversos tipos de reloj de sol, basada en las fuentes literarias griegas y latinas, ha sido realizado por S.L. GibBs, Greek and Roman Sundials, New Haven-London 1976 , especialmente 119 y ss. 


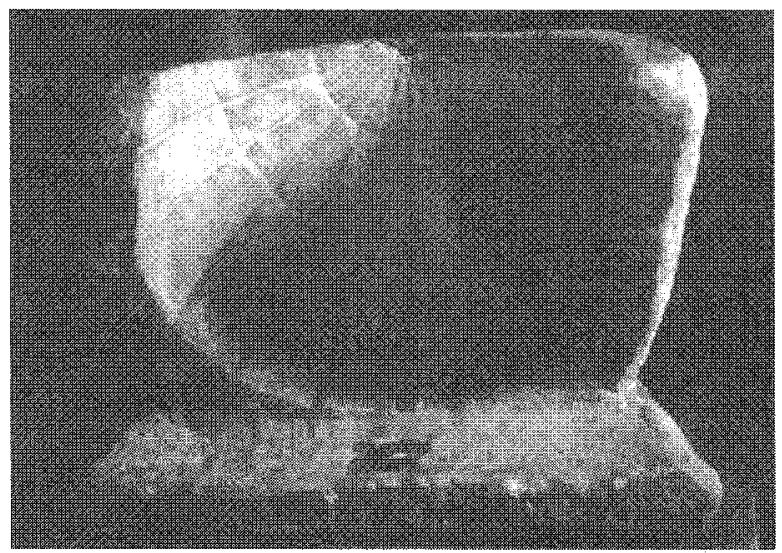

Figura 8. Reloj de mármol. Museos Vaticanos. (Foto G. López Monteagudo).

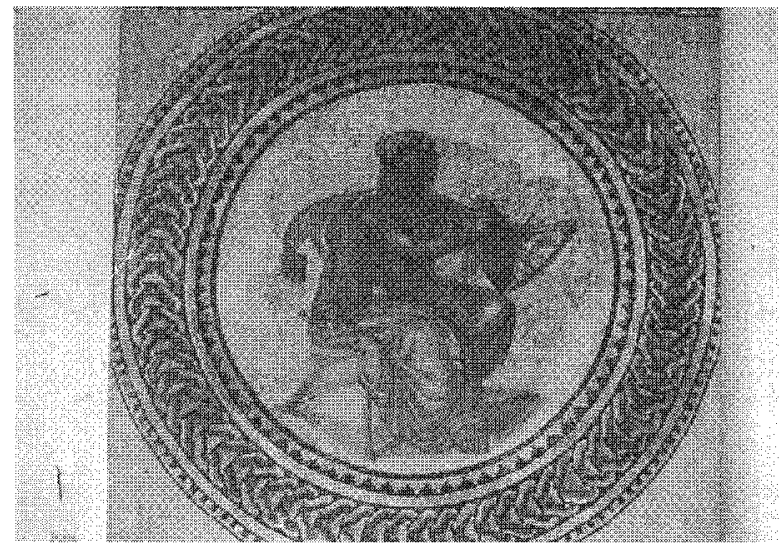

Figura 9. Mosaico de Trier. (Foto G. López Monteagudo).

como por las musas ${ }^{22}$. K. Parlasca identifica al personaje como Anaximandro, por haber sido este sabio el inventor del reloj de sol, y fecha el panel a comienzos de la época severiana ${ }^{23}$. El tipo de reloj solar representado en este

22 E| klismos (cathedra) fué muy frecuente en el arte griego de los siglos $V$ y IV a.C., derivando en época romana directamente de los modelos helenísticos, cf. G.M.A. RICHTER, Ancient Furniture, Oxford 1926, 45-53, 127-129. El tipo perdura en miniatura de Hipócrates del Códice de Hipócrates de la Biblioteca Nacional de Paris (MSS. grecs 2144, f. 10), cf. G.M.A. RICHTER, The Portraits of the Greeks, London 1965, I, 153, Fig. 869.

23 K. ParlascA, Die römischen Mosaiken in Deutschland, 1959, 29, Taff. A y 28.2. 
mosaico pertenece al llamado "pelecinum» (Fig. 10), del que existen varias representaciones en sarcófagos y relieves romanos del siglo III, así como también en sarcófagos cristianos con escenas del «último viaje». El «pelecinum» es citado por Vitruvio (IX, VIII, 1) y M. Cetius Faventinus (Liber artis architectonicae, cap. XXIX), autor este último que vivió en el siglo III o en torno al 300 d.C., como un reloj formado por dos hojas de mármol o piedra más anchas por la parte superior que por la inferior ${ }^{24}$. Fue inventado por Patrocles, científico que vivió entre la segunda mitad del siglo IV a.C. y el último cuarto del siglo III a.C., por lo que el personaje representado en el pavimento de Trier podría ser Patrocles y no Anaximandro.

En otros paneles se han representado los descubrimientos científicos sin relación con sus creadores. Este es el caso del reloj de sol que aparece en

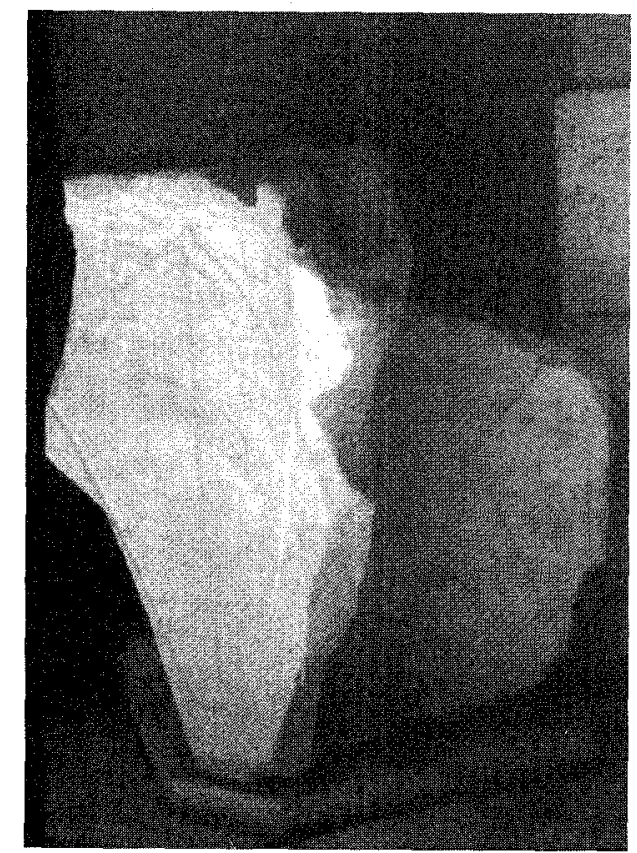

Figura 10. Reloj de mármol. Museos Vaticanos. (Foto G. López Monteagudo).

24 Sobre el tipo de reloj llamado pelecinum, cf. G. TRAVERSARI, II "pelecinum». Un particolare tipo di orologio solare raffigurato su alcuni relievi di sarcofagi di età romana, Colloquio Internazionale Archeologia e Astronomia (Venezia 1989), suppl. alla RdA 9, Roma 1991, 66-73, con toda la bibliografía. 
el cuadro XXVI del mosaico del Calendario agrícola de Saint-Roman-enGal, fechado en la primera mitad del siglo III. La escena muestra a dos personajes que se disponen a dar pez a las vasija destinada a contener aceite; en un segundo plano se ve un árbol sin hojas, alusión de que la acción tiene lugar en el mes de diciembre, y a la izquierda una columna rosa-granate coronada por un reloj de sol en los mismos tonos. En comparación con los relojes de sol representados en los mosaicos de Torre Annunziata, Sarsina, Brading y Antioquía (vid. infra), éste de Saint-Roman-en-Gal está realizado de manera muy burda, en forma de triángulo de base convexa y carece de las ranuras correspondientes a las horas. J. Lancha opina que el reloj no se ha puesto para indicar una hora, sino un momento del año, que podría ser el solsticio de invierno, el 21 de diciembre, convención análoga en el cuadro asociado al mes de junio en el calendario de Filocalus para indicar el solsticio de verano, lo que mostraría una vez más la estrecha correspondencia entre los menólogos romanos del siglo I, que sitúan la fabricación del aceite en diciembre, y el calendario francés ${ }^{25}$.

En la Casa del reloj del sol de la villa constantiniana de Antioquía, se descubrió un mosaico muy destruido, fechado a comienzos del siglo III, del que solo quedaban en el momento de su hallazgo un panel rectangular (B) decorado con dos bustos, uno masculino y otro femenino, identificados por Levi como Dionysos y Ariadna; y en los ángulos dos paneles ( $A$ y $C$ ) en cada uno de los cuales se ha representado una figura masculina, de pie y en actitud declamatoria junto a un reloj de sol colocado sobre alta columna cilíndrica, habiéndose perdido el del panel A. Ambos tienen el cabello de color gris, llevan barba y van vestidos con túnica y manto. En el panel $\mathrm{C}$ una inscripción en griego indica que «la hora novena ha pasado", pudiéndose hacer una lectura tanto pagana (Mart. IV 8) como cristiana ${ }^{26}$.

El tema de los sabios reunidos en simposio se vuelve a encontrar en un mosaico hispano de mediados del siglo IV, procedente de Mérida, así como en un pavimento del edificio pagano descubierto debajo de la catedral de Apamea de Siria, del tercer cuarto del siglo IV.

\footnotetext{
25 H. SteRn, Le calendrier de 354, Paris 1953, 205 y ss.; Id., Les calendriers romains illustrés, ANRW II 12.2, 1981, 431 y ss., pl. XVI y XIX 53; RGMG III-2, 1981, 218-224, n² 368, pl. CXIXb.

26 R. StILlwell, Antioch on-the-Orontes II, Princeton 1938, 202, PI. 75; D. LEVI, Antioch Mosaic Pavements, Princeton 1947, 219-221, pl. XLIX a-b. No es una casualidad que en el pavimento de otra habitación de esta misma casa (Room 3) aparezcan las musas asociadas a un emblema de tipo dionisiaco, cf. L. BUDDE, Antike Mosaiken in Kilikien, I1, 1972, Abb. 196; E. THEOPHILIDOU, Die Musenmosaiken der römischen Kaiserzeit, TZ 47, 1984, 261, confirmando una vez más la relación simbólica entre los sabios, las musas y los temas báquicos (vid. infra).
} 
El mosaico de los Sabios hallado en Mérida, conservado en el Museo de Arte Romano de Mérida, ofrece una composición un poco heterodoxa de la escena del simposion de los sabios sentados en exedra. Sin embargo, los siete Sabios de Grecia están representados siguiendo la iconografía tradicional e identificados por rótulos con sus nombres en griego, conforme al canon admitido desde Demetrios de Phalere (Stob. III 79; XLIII 131) y en el orden enumerado por Diógenes Laercio (Diog. Laert. I 5186). En la cabecera se han representado a Quilón de Lacedemonia y a Tales de Mileto (Fig. 11) que presiden el simposion; a la izquierda de Tales se sientan Bías de Priene, Períandro de Corinto y Cleóbulo de Lindos; enfrente de éstos y a la derecha de Quilón se disponen un sabio cuyo nombre se ha perdido, tal vez Pítaco de Mitilene, y Solón de Atenas.

En la parte de abajo se ha figurado una escena en la que intervienen cuatro personajes, identificados por J.M. Alvarez Martínez de izquierda a derecha como Agamenón, Aquiles, Ulises y Briseida, simbolizando el episodio de la "cólera de Aquiles» de una forma un tanto heterodoxa y en nada coincidente con lo especificado por Homero (1/. I 94 ss.). Según este autor lo que se intenta mostrar en la escena no es tanto el episodio épico como el concepto psicológico de la "cólera de Aquiles», es decir la actitud de Aquiles ante Agamenón en presencia de Ulises como símbolo de la prudencia, que sería el tema de reflexión de los sabios reunidos en simposion ${ }^{27}$. M.-H. Quet interpreta esta escena como el rapto de Briseida,

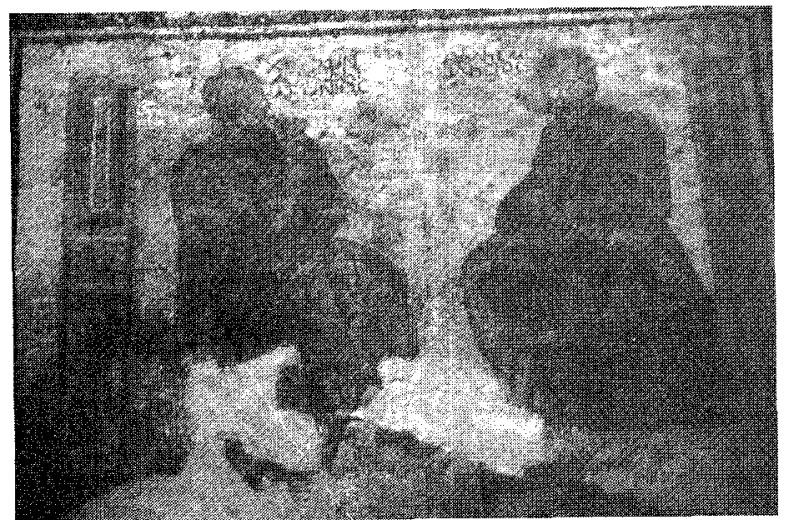

Figura 11. Mosaico de Mérida. Quilón y Tales. (Foto G. López Monteagudo).

27 J.M. Alvarez Martínez, El mosaico de los siete sabios hallado en Mérida, Anas l, 1988, 99 y ss.; Idem, Mosaicos romanos de Mérida. Nuevos hallazgos, Mérida 1990, 69 y ss. 
episodio épico evocado por Homero (II. | 298-304) y frecuentemente representado en la iconografía tardía. Para la autora existe una relación semántica entre el registro filosófico y el épiço, siendo la figura de Cleóbulo el nexo de unión iconográfico e intelectual entre ambas escenas. El sabio, que era famoso por sus máximas y enigmas: «la medida es la mejor de las cosas", "la virtud consiste en abstenerse del mal», "es preciso huir de la injusticia, dominar las pasiones, evitar la violencia», aparece vuelto hacia la parte inferior del cuadro en una actitud de advertencia hacia el dominio de las pasiones humanas. Es pues, una exégesis moralizante de contenido más o menos alegórico el tema de conversación de los sabios reunidos en «banquete», práctica que en los siglos III y IV era usual en las escuelas filosóficas tanto de los estóicos y neoplatónicos como de los simples sofistas (Dion Prus. Or. 53, 11-12; 55, 9 y 19; 56, 11-16; 61, 1 y 5) ${ }^{28}$. Aparte de las distintas interpretaciones que se le puedan dar al mosaico de Mérida, la relación entre ambas escenas se explica porque, según señala Homero (II. II 405 ss.; III 146 ss.), tanto Agamenón como Príamo eran aconsejados por un grupo de siete experimentados notables.

En el pavimento de Apamea (Fig. 12), que forma parte de un conjunto de mosaicos procedentes del edificio pagano situado debajo de la catedral

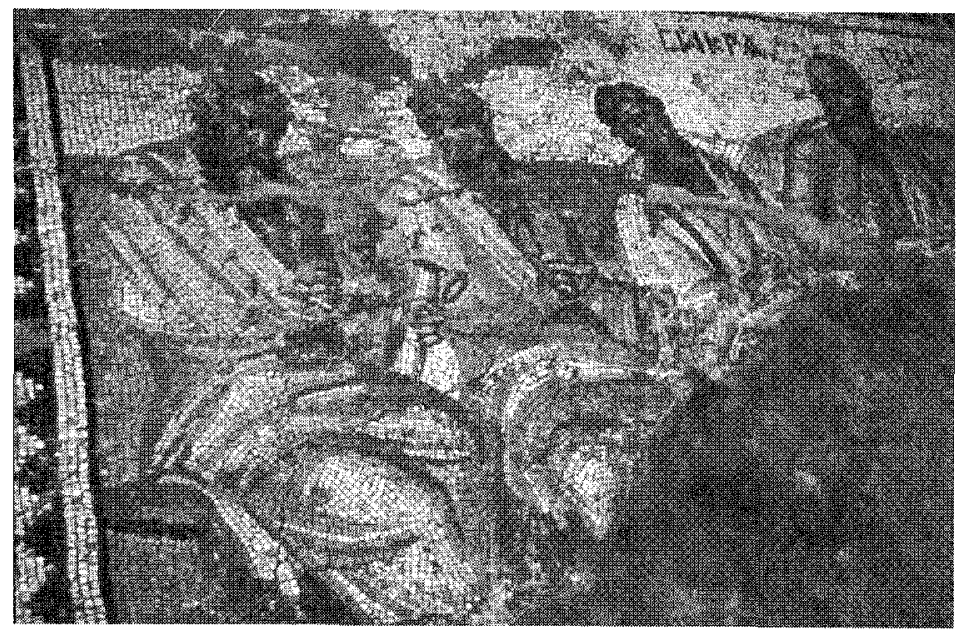

Figura 12. Mosaico de Apamea. (Foto G. López Monteagudo).

${ }_{28}$ M.-H. QUET, Banquet de Sept Sages et sagesse d'Homère. La mosaïque des Sept Sages de Mérida, BSBReinach 5, 1987, 47-55. 
datables en $362-363$, Sócrates preside una asamblea de seis sabios representados como hombres de edad madura y barbados, vestidos con el pallium de los filósofos y llevando muchos de ellos un rollo en la mano, sentados en una exedra a la manera tradicional del simposion. Sócrates, en el centro, está identificado por su nombre en griego; tiene la mano derecha levantada, en ademán de enseñanza como en el mosaico de Mitilene (vid. infra), gesto que más tarde será el de la benedictio latina ${ }^{29}$. Iconográficamente muestra un estrecho parecido con una pintura procedente de la Casa del Actor Trágico en Sabratha y con otra de Efeso (Fig. 13), identificada por una inscripción en griego y datada en el siglo I d.C., que para J. y J.Ch. Balty sería el original del que derivaría el retrato sirio ${ }^{30}$.

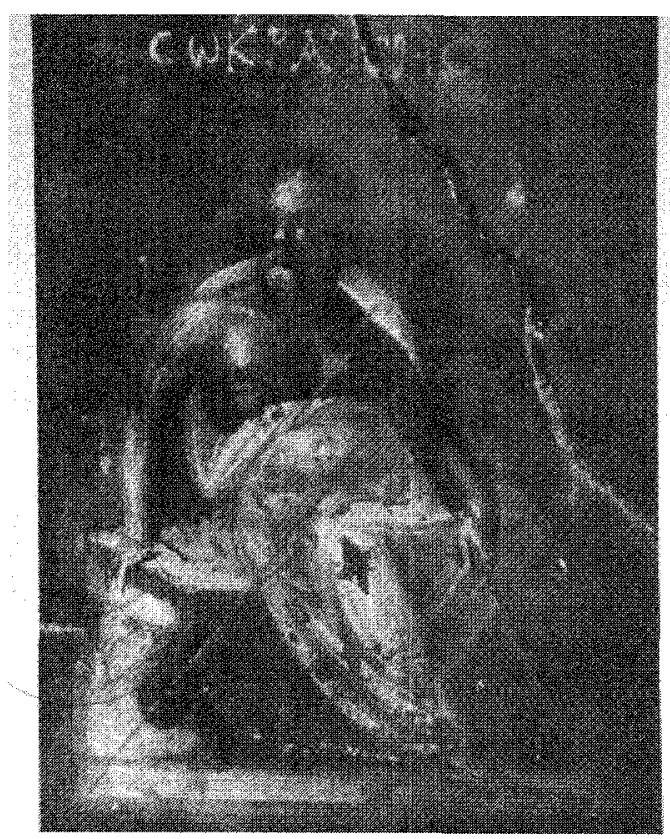

Figura 13. Pintura de Efeso. Sócrates.

29 G.M.A. HANFMANN, Socrates and Christ, Harvard Studies in Classical Philology 60, 1951, 205 y ss.; J.-J. CH. BALTY, Apameé de Syrie. Bilan de recherches archéologiques 1969-1971, Bruxelles 1972, 166 y ss.; J. BALTY, Mosaïques antiques de Syrie, Bruxelles 1977, 78-80; J. CH. BALTY, Guide d'Apamée, Bruxelles 1981, 187-191.

30 S. Aurigemma, L'Italia in Africa. Le pitture d'età romana, Roma 1962, 105, Tav. 103; G.M.A. RichTER, The Portraits of the Greeks, London 1965, 1, 119, Fig. 563a.; J.-J. CH. BALTY, Apameé de Syrie. Bilan de recherches archéologiques 1969-1971, Bruxelles 1972, 166 y ss. 
El número de personajes representados en esta escena coincide con el del Symposium de Platón, donde se encuentran siete oradores incluyendo a Sócrates. Su identificación, sin embargo, es más discutida ya que Diógenes Laercio (II 47,5) nombra a Platón, Jenofonte y Antístines como los discípulos más distinguidos de Sócrates, lo que da pie a G.M.A. Hanfmann para identificar a Platón con el segundo personaje de la derecha, al cínico Antístines con uno de los dos filósofos situados a la derecha de Sócrates o también con el que se halla en el centro del ala izquierda, y a Aristipo, el apóstol del placer, como el elegante personaje sentado a la izquierda de Sócrates. Las diferencias entre los retratados y la comparación con los sabios del mosaico de Baalbeck (vid. infra), en donde están identificados por inscripciones con sus nombres y máximas, llevan a J. Balty a reconocer de izquierda a derecha a Cleóbulo, Períandro, Bías, y a la derecha de Sócrates a Tales, Solón y Quilón, este último por su parecido con el Quilón de la sala $A B$ del triclinio de Apamea (vid. infra). El grupo de la izquierda, integrado por Cleóbulo, Períandro y Bías, se documenta igualmente en el mosaico de Mérida (vid. supra), aunque aquí ocupan el lado derecho y su identificación no ofrece dudas por cuanto que aparecen acompañados de inscripciones con su nombre. Se ha supuesto que el tema de conversación de los sabios en este pavimento es la Belleza o la Gracia, por las inscripciones «Kallos» y «Charis» que aparecen en un emblema del pavimento geométrico adyacente y por el tema representado en el panel rectangular próximo sobre el Juicio de las Nereidas, todos pertenecientes al mismo programa decorativo; aunque también podría tratarse de la Sabiduría como medio de alcanzar la inmortalidad, contenido del cuadro de Ulises y las Therapénides, contiguo al panel de los Sabios, y de la corona de la inmortalidad con la inscripción «haz buen uso», que decora el emblema de otra habitación del mismo conjunto.

Según Ch. Picard el tipo derivaría de la exedra del serapeion de Menfis, monumento sagrado dionisiaco de época helenística, adornado con las estatuas de cinco poetas y cinco filósofos presididos por Homero (vid. infra) ${ }^{31}$. Como acertadamente piensan G.M.A. Hanfmann y J. Balty, existen grandes similitudes entre esta composición con la representación de Sócrates rodeado de los Sabios y las escenas del arte paleocristiano, en donde la figura de Cristo aparece igualmente rodeado por seis de sus discípulos dispuestos en grupos de tres a cada lado del maestro; baste recordar las pinturas de la catacumba de la Vía Latina en Roma, datadas a

31 J.-PH. LAVER - CH. PICARD, Les statues ptolemaïques du Serapeion de Memphis, Paris 1955,38 y ss. 
mediados del siglo IV e interpretadas por algunos investigadores como un tema pagano, o las conservadas en el ábside de la iglesia de Santa Pudenciana en Roma, de fines del siglo IV o comienzos del $V{ }^{32}$. Según G.M.A. Hanfmann, los apologistas cristianos, Clemente de Alejandría, Orígenes y Tertuliano (de anima 1300 ) comenzaron pronto a comparar la figura de Cristo con la de Sócrates, así Justino (Apologia 15, II 10) insiste en el cristianismo como enseñanza, enfatizando el aspecto de Cristo como maestro que se encuentra en el arte; y Eusebio (Hist. eccl. IV 11, 8; IV 17,1 ; II 3) escribe que los apologistas cristianos se presentaban como filósofos y vestían a la manera de los filósofos profesionales. Concluye este autor que el modelo adoptado para representar a Cristo y sus discípulos fué el mismo que el utilizado en el mosaico de Apamea. Para J. Balty hay que pensar más que en una comunidad de modelos, en una «repaganización» o «descristianización» de la figura de Cristo, suplantada por la de Sócrates, dentro de proceso de rehelenización impulsado por el emperador Juliano ${ }^{33}$.

Al mismo grupo de sabios reunidos en simposion pertenece, casi con toda seguridad, la escena representada en un panel fragmentario procedente de la villa de Soueidé, en Baalbeck. De ella solo se ha conservado la mitad derecha de una figura masculina sentada en el extremo de un banco, vestida con pallium, con cabello y barba negros, identificada por la inscripción que la acompaña como Aristóteles, que fue maestro de Alejandro durante tres años (Plut. Alex. 8). El tipo iconográfico no se ajusta a los retratos conocidos del filósofo de época clásica, sino que sigue el modelo utilizado para la representación de Sócrates en los mosaicos de Baalbeck ( $v i d$. infra) y de Apamea (vid. supra). La disposición de la figura en el extremo de lo que parece ser un banco en exedra y el espacio restante hacen pensar en una escena de banquete de sabios. En este caso, los sabios se hallan en relación con la educación de Alejandro, cuyo nacimiento se ha figurado en otro mosaico de la misma habitación. M. Chéhab fecha el conjunto a fines del siglo IV, probablemente un siglo antes de la dispersión de la escuela neoplatónica a la muerte de Proclus ${ }^{34}$.

32 P. BoyancÉ, Aristote sur une peinture de la via Latina, Mélanges E. Tisserant $N$, Studi e Testi 234, Città di Vaticano 1964, 1-95; G. BoviNI, Mosaici paleocristiani di Roma (Secoli III-VI), Bologna 1971, 81 y ss.

33 G.M.A. Hanfmann, Socrates and Christ, Harvard Studies in Classical Philology 60, 1951, 214; J. BALTY, Un programme philosophique sous la cathédrale d'Apamée: l'ensemble neo-platonicien de l'empereur Julien, Texte et Image, Paris 1984, 167 y ss.; Id., Iconographie et réaction paĩenne, Melanges $P$. Lévêque, 1, Paris 1988, 17 y ss. Según esta autora habría que considerar el conjunto de los mosaicos de Apamea como ilustración de la doctrina neoplatónica del alma.

34 M. CHÉHAB, Mosaïques du Liban, BMB XIV, Paris 1958, 48-49, p1. XXIII, 1. 
Todas estas escenas tienen en común el ser representaciones de sabios reunidos en simposion, tema que se documenta desde época helenística en el relieve funerario del rodio Hieronymos (Fig. 14), del siglo III a.C.: la escena se desarrolla en un friso corrido y en ella, comenzando por la izquierda, se ve un banco en forma de exedra con patas de león donde están sentados tres personajes; el primero oculta las dos manos debajo del manto, le sigue otro vestido con himation que sostiene un rollo abierto en la mano derecha y dirige la mirada hacia el que está sentado al final del banco a la derecha, el cual lleva un bastón o vara; junto a él y detrás del banco se encuentra otro personaje en pie, vestido con himation bajo el que oculta su brazo izquierdo y deja libre el derecho que apoya en el hombro del anterior; detrás del banco se halla un joven con el torso al descubierto y a su izquierda parece adivinarse otra figura en pie ${ }^{35}$; en el

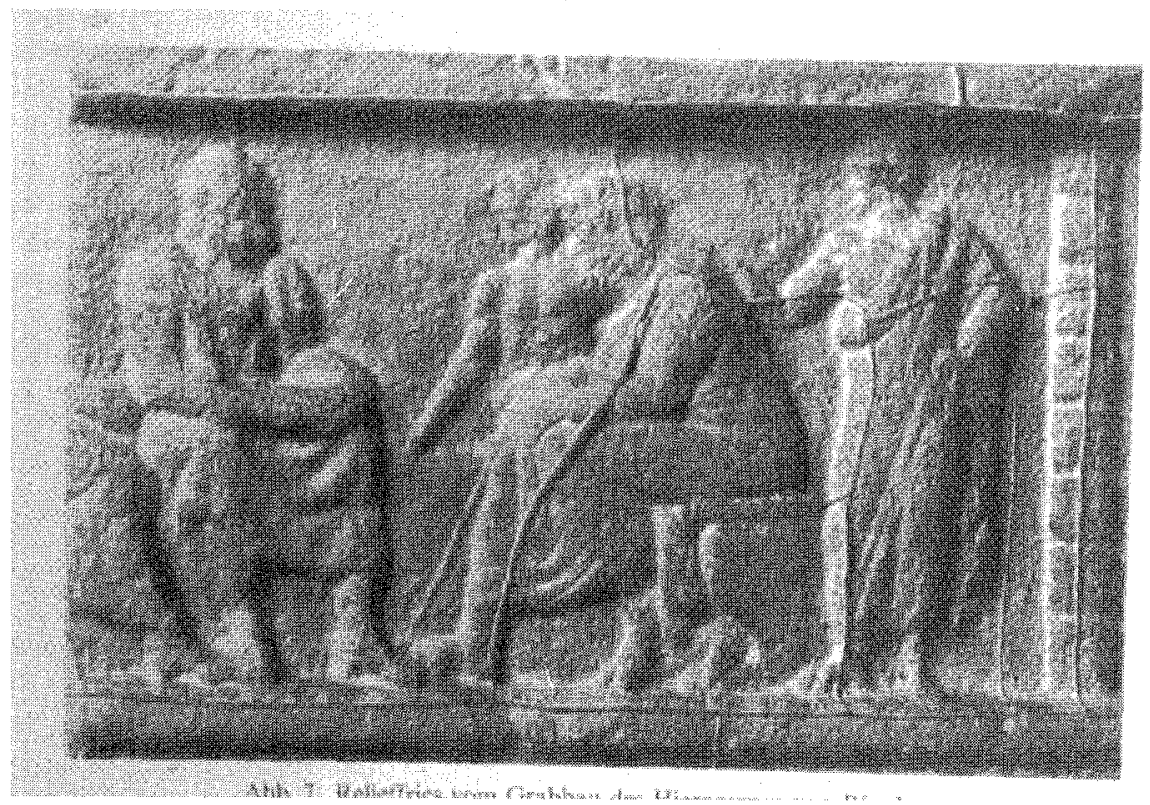

Figura 14. Relieve de Hieronymos.

35 P.M. Fraser, Rhodian Funerary Monuments, Oxford 1977, 34-36, pl. 97; E. PfuHL - H. Möblus, Die ostgriechischen Grabrelief, Mainz 1979, II, 501; A. SCHOLL, Polytalanta Mnemeia. Zur litterarischen und monumentalen Uberlieferung aufwendiger Grabmäler im spätantiken Athen, Jdl 109, 1994, 247-249, Abb. 7 . 
citado Serapeion de Menfis (Fig. 15), de la misma fecha: el monumento, levantado en época de Ptolomeo I, formaba un semicírculo ornado con diez grandes estatuas de poetas y filósofos, unos sentados y otros en pie, acompañados de "grafitti» con sus nombres aún legibles en el momento de su descubrimiento, que han permitido identificar a uno de los lados de la figura central de Homero, sentado en un trono presidiendo el grupo, a Píndaro con volumen en la mano izquierda, Demetrios de Phalere que sujeta sus cabellos con una diadema y Hesíodo, junto a dos figuras no identificadas; al otro lado de Homero se hallan los sabios-filósofos entre los que se distingue a Protágoras, profesor de matemáticas, sosteniendo con ambas manos una caja cúbica; Heráclito y Platón, además de un personaje no identificado que en pie y con la pierna doblada sobre una capsa, señala con un puntero hacia algo colocado en el suelo ${ }^{36}$; en frescos de época hadrianea hallados en el «Palazzo dei Cesari» de Ostia, donde se han figurado los sabios sentados acompañados de sus nombres y máximas, y, al parecer, también en una pintura hallada en Pompeya, hoy

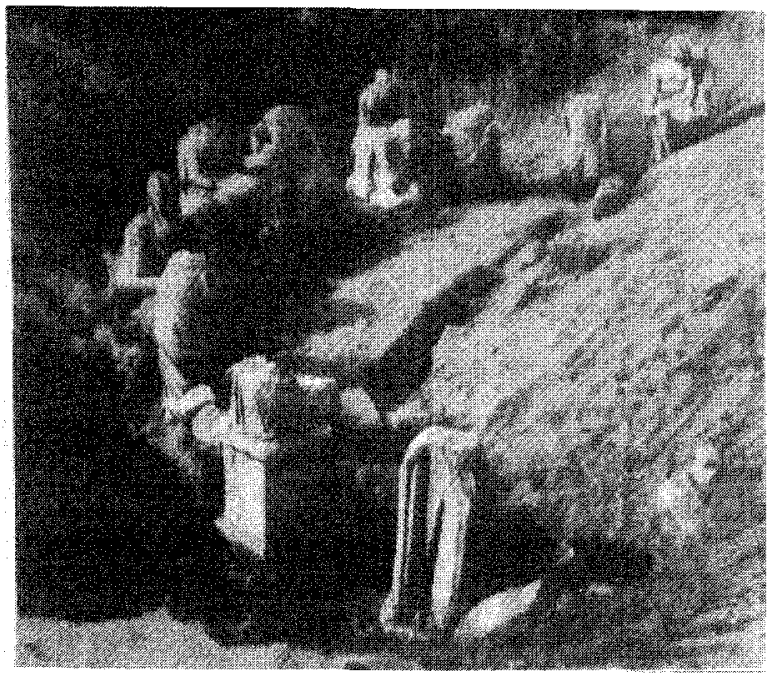

Figura 15. Esculturas del Serapeion de Menfis.

36 J.-PH. Laver - Ch. PICARd, Les statues ptolemaïques du Serapeion de Memphis, Paris 1955, 38 y ss. La semejanza iconográfica de algunos de estos personajes, jdentificados por su nombre, con otros anepígrafos representados en los mosaicos de Torre Annunziata y Sarsina hace posible la identificación de algunos de estos. 
perdida, en la que se representaban doce figuras conversando, unas sentadas y otras de pie, identificadas por G. Calza como sabios ${ }^{37}$; en una gema de Cambridge (Fig. 16), de fines del siglo II d.C.: la escena representa a siete filósofos o sabios reunidos en medio círculo en torno a la esfera, pudiéndose identificar a Solón con el quinto personaje por el «petasos" que lleva sobre la cabeza ${ }^{38}$; o en obras ya cristianizadas pero que siguen la antigua tradición del grupo canónico reunido en exedra, como son el plato polícromo del Museo Nazionale Romano, datado a fines del siglo III d.C. ${ }^{39}$; el fresco de la Catacumba de la Vía Latina en Roma ${ }^{40}$; la caja de marfil de Brescia ${ }^{41}$; la placa de terracota de la Dumbarton Oaks Collection ${ }^{42}$, obras todas del siglo IV, perdurando la misma composición en el código vienés de Dioskurides, que se fecha ya en el siglo VI: miniatura con dos pinturas en cada una de las cuales están representados en forma de exedra los siete médicos o farmacólogos de la ciencia médica griega:

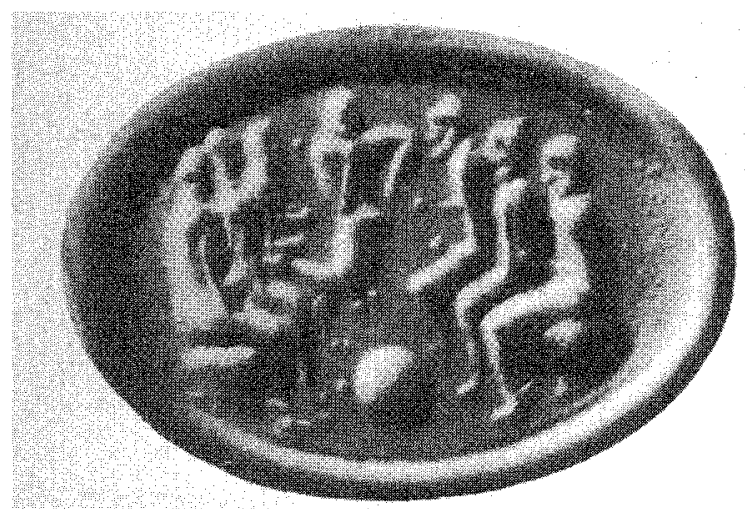

Figura 16. Gema de Cambridge.

37 G. CalzA, Die Taverne der Sieben Weisen in Ostia, Die Antike 15, 1939, 99 y ss.

38 A. FurtwängleR, Die antiken Gemmen III, Leipzig-Berlin 1900, 166; G.M.A. Richter, Some Italic and Roman Engraved Gems in Cambridge, Hommages à L. Herrmann, coll. Latomus 44 , $1960,671-674$.

39 K. Weitzmann, Age of Spirituality, New York 1979, núms. 372-373

40 P. BoyancÉ, Aristote sur une peinture de la via Latina, Mélanges E. Tisserant IV, Studi e Testi 234, Città di Vaticano 1964, 1-95. P. Boyancé cree que la escena representa el diálogo de Aristóteles y sus discípulos, aunque el contexto sugiere más bien un simbolismo en relación con las creencias cristianas en la Otra Vida.

41 G.W. ElderkIN, Mosaics of the Seven Sages, RM 52, 1937, 103.

42 G.M.A. HANFmann, Socrates and Christ, Harvard Studies in Classical Philology 60, 1951, 205 y ss., Fig. 4, 6 y 7 
Andreas, Apollonios, Kratenas, Galenos, Dioskurides, Nikander y Rufus; Xenocrates de Afrodisias, Pamphilos, Machaon, Chiron, Nigros, Herakleides de Tarento y Mantias ${ }^{43}$. La iconografía se repite en el Menologio de Basilio II (Vat. gr. 1613; fol. 108), de fines del siglo X. Otro grupo afín, aunque aquí son nueve las figuras reunidas en simposion, lo constituye el manuscrito de los Agrimensores (Pal. lat. 1564; fol. 2), del siglo IX (Fig. 17), que sigue modelos de un códice ilustrado de los siglos VII-VIII. Doce figuras sentadas en exedra ilustran las Homilías de Giacomo, monje de Kokkinobaphos (Vat. gr. 1162; fol. 2), ya del siglo XIi ${ }^{44}$.

Sin embargo, aunque el esquema compositivo es prácticamente idéntico, existen algunas diferencias en cuanto al contenido de la composición.

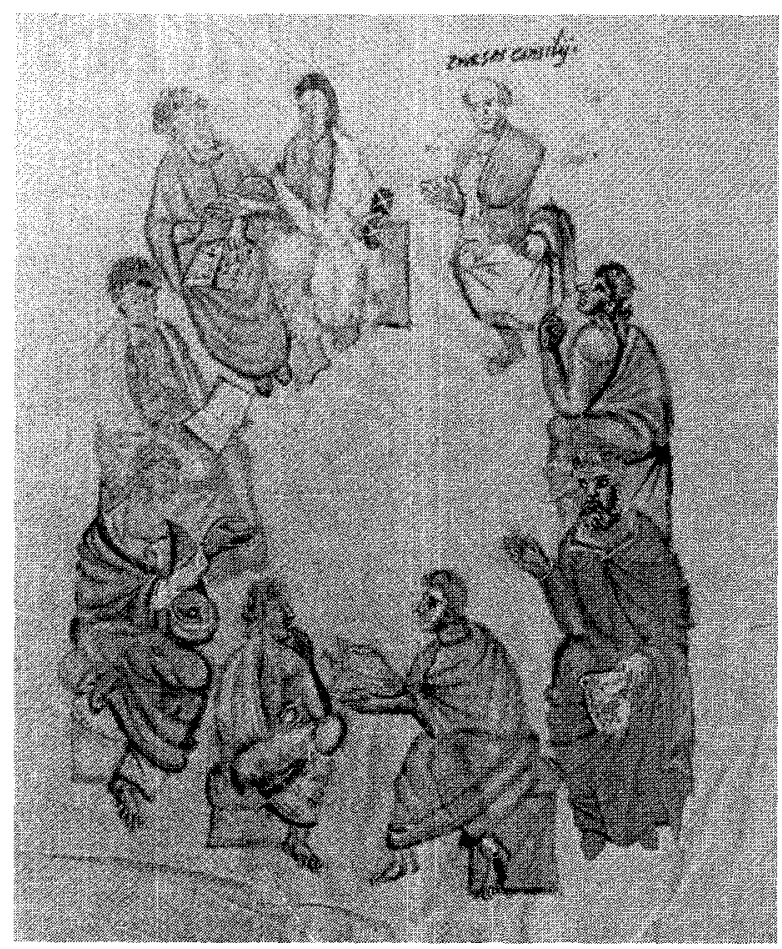

Figura 17. Manuscrito de los Agrimensores (Pal. lat. 1564; fol. 2). 
Y así se observa cómo en los mosaicos de Torre Annunziata y Sarsina la atención está concentrada en el instrumento científico, que en este caso es la esfera, habiéndose representado a los sabios o filósofos de forma individual agrupados libremente, al contrario de lo que ocurre en el pavimento de Apamea y en las representaciones cristianas, donde existe una figura central que enfatiza el papel del maestro rodeado de los discípulos. Un tipo mixto estaría constituido por el mosaico de Mérida, la gema de Cambridge y el relieve de Hieronymos. Según K. Gaiser, el modelo para todos ellos pudo haber sido una antigua pintura griega de personajes conversando, prototipo directo del relieve funerario de Rodas, donde hay seis o siete figuras, unas sentadas en un banco en forma de exedra y otras en pie, en las que quizás no hay que ver una representación de sabios reunidos en simposion, sino simplemente a unos personajes conversando. En opinión de este autor, la identificación de uno de los personajes representados en el mosaico de Torre Annunziata con Eratóstenes, cuya tumba se localizaba en Alejandría según el epigrama de Dionysios de Kyzikos (Anthol. Pal. VII 78), hace suponer que el original griego debía encontrarse en el Museion alejandrino de la Academia platónica, a cuya biblioteca aludirían los rollos y la caja representados en el mosaico ${ }^{45}$.

Una variante del tema de los sabios conversando se encuentra en un panel procedente del triclinio T de Mitilene (Fig. 18), fechado a comienzos del siglo IV o del V, en donde se ha representado a Sócrates en diálogo con sus discípulos y amigos, los tebanos Simmias y Kebes, identificados por inscripciones en griego. Los tres personajes están en pie en posición frontal, Sócrates en el centro, en actitudes didácticas muy semejantes con la mano derecha levantada y la izquierda sosteniendo un rollo, que recuerdan a algunas de las figuras del mosaico de los literatos de Trier (vid. infra). Visten túnica y manto y los tres llevan barba y cabellos largos. K. Gaiser opina que se trata de una representación del "Phaidon» de Platón o del «Plokion» de Menandro, ya que en otros paneles aparece el retrato de este último, una escena de su obra «Plokion» y la musa Talía, todos ellos identificados por inscripciones ${ }^{46}$.

45 K. Galser, Das Philosophenmosaik in Neapel, Heidelberg 1980, 92-103. Sobre el Museion y la Biblioteca de Alejandría, cf. P.M. Fraser, Ptolemaic Alexandria, Oxford 1972, con referencias también a Eratóstenes como matemático.

46 Datado en el 300 por S. Charitonidis, cf. S. ChaRITONIDIS-L. KaHIL-R. GinouvES, Les mosaïques de la Maison de Ménandre à Mytilène, 1970, 33-36, pl. 3.2; y en el 400 por Berczelly, cf. L. BerCzelly, The Date and Significance of the Menander Mosaics at Mytilene, BICS 35, 1988, 119126. Las imágenes de los actores tal vez sirvieron de prototipo a las miniatura del códice de Terencio Vaticano (Vat. lat. 3868; fol. 55), fechado en el siglo IX, dadas las estrechas analogias entre unas y otras, cf. Biblioteca Apostólica Vaticana, Madrid 1987, 54, lám. IX. 


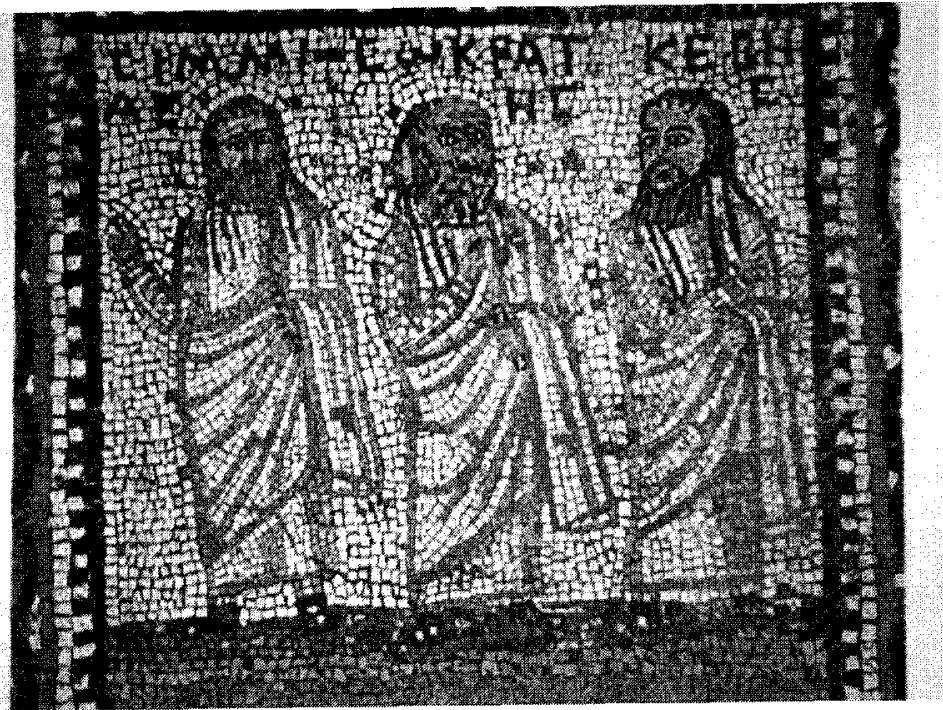

Figura 18. Mosaico de Mitilene. Sócrates, Simmias y Kebes.

Sócrates aparece representado en mosaicos de Apamea (vid. supra), Baalbeck y Colonia (vid. infra) de forma más o menos ajustada a los retratos tradicionales del filosófo inspirados en modelos helenísticos; pero en el pavimento de Mitilene no se ha pretendido hacer retratos realistas, sino imágenes convencionales de filósofos, que más tarde pasarán al arte paleocristiano en la iconografía de Cristo y sus discípulos. L. Berczelly compara la composición del mosaico de Mitilene con el grupo similar representado en el sarcófago de columnas de la catacumba de San Sebastián en Roma, fechado en 360-370 - al que habría que añadir las pinturas de las catacumbas de Domitila y de Pedro y Marcelino- y opina que la escena de Mitilene forma parte de la reacción pagana contra el cristianismo al adoptar temas cristianos como método de propaganda anticristiana, ya que es sabido el importante papel que juega la figura de Sócrates en la propaganda de la resistencia pagana al cristianismo ${ }^{47}$. El tema se perpetúa en el arte medieval, baste recordar el códice constituido por el Martirologio de Beda y las obras de astronomía y de cómputo y el de natura rerum de Isidoro

47 L. Berczelly, The Date and Significance of the Menander Mosaics at Mytilene, BICS 35, 1988, 119-126; G.M.A. Hanfmann, Socrates and Christ, Harvard Studies in Classical Philology 60, 1951, 221 y ss.; J. - J.-CH. BALTY, Julien et Apamée. Aspects de la restauration de l'hellenisme et de la politique antichrétienne de l'empereur, Dialoges d'Histoire Ancienne I, 1974, 276. 
(Pal. lat. 834; fol. 28), del siglo IX (Fig. 19), donde aparecen tres figuras nimbadas, dos de ellas con un rollo en la mano derecha y la tercera sosteniendo un libro en la izquierda, que tal vez pueden identificarse con Cristo y dos de sus discípulos ${ }^{48}$.

En todas estas representaciones está claramente explícito el tema de conversación o de discusión de los sabios, al contrario de lo que ocurre en otros pavimentos en donde no existe carácter de banquete o reunión disquisitoria, a pesar de que los sabios aparezcan agrupados por lo general en forma de busto y presididos por Sócrates, acompañados de sus rótulos identificativos y a veces también de las sentencias que les hicieron famosos. Un buen ejemplo de esta modalidad la constituye el pavimento procedente del triclinio de la villa romana de Soueidié, en Baalbeck, fechado en la segunda mitad del siglo III, con los bustos de Sócrates y siete sabios dispuestos alrededor de Calíope, formando una composición de ocho círculos entrelazados en torno al círculo central ${ }^{49}$.

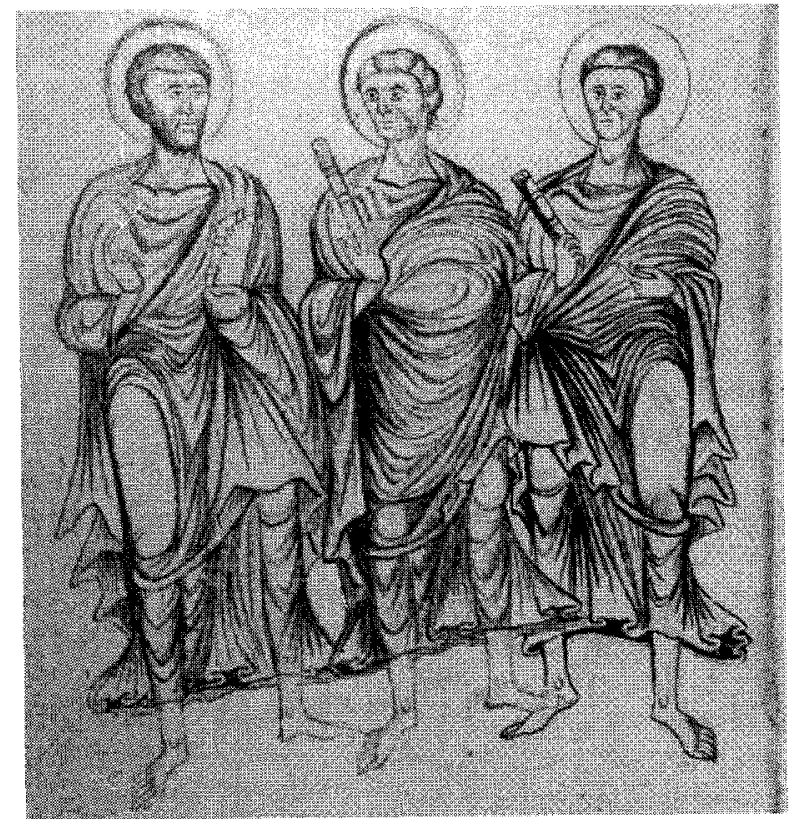

Figura 19. Códice del siglo IX (Pal. lat. 834; fol. 28).

48 Cf. Biblioteca Apostólica Vaticana, Madrid 1987, 58, lám. XII.

49 M. ChéHAB, Mosaïques du Liban, Bull. M. de Beyrouth XIV, 1958, 29-36, pl. XV-XX. 
En el centro aparece el busto de la musa Calíope vestida con túnica y manto drapeado, del que sale la mano derecha sosteniendo un volumen enrollado. Adorna la cabeza con una diadema en forma de creciente coronada por un penacho. A ambos lados de la musa sendas inscripciones en griego dan a conocer a la izquierda su nombre, «Calíope», y a la derecha el del artista, «Anfeion es el autor». Los bustos de los sabios van acompañados también de inscripciones en griego indicativas de sus nombres, sus ciudades de origen y de las máximas que les hicieron famosos. En el medallón superior está representado «Sócrates de Atenas» (Fig. 20) y a su derecha, de arriba hacia abajo, «Solón de Atenas. Nada en exceso», «Tales de Mileto. La fianza lleva a la ruina» y «Bías de Priene. La mayoría de los hombres son malos"; a la izquierda del sabio se disponen los bustos de «Quilón de Lacedemonia. Conócete a tí mismo», «Pítacos de Lesbos. Aprovecha la oportunidad» y «Períandro de Corinto. La reflexión apresura la obra». En el medallón de abajo, enfrentado al de Sócrates, se ha representado a "Cleóbulos de Lindos. La medida en todo es lo mejor». Todos están representados como hombres de edad madura y barbados, llevan pallium de color blanco o amarillo que les cubre ambos o solo uno de los hombros, y sus rasgos fisonómicos son tan distintivos

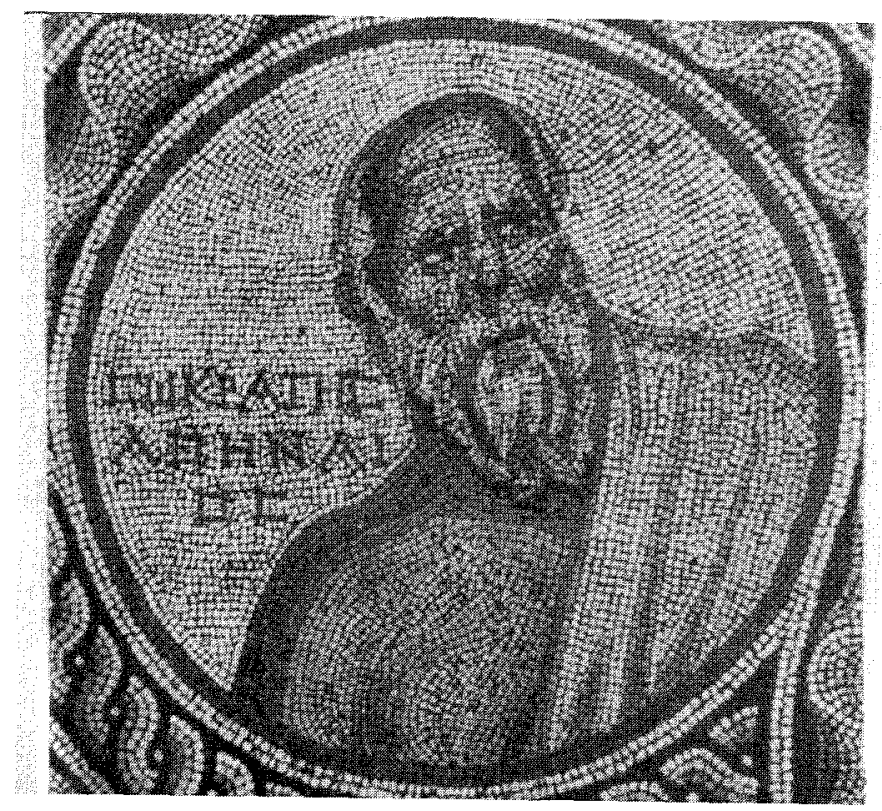

Figura 20. Mosaico de Baalbeck. Sócrates. 
que, aunque faltaran las inscripciones, sería posible su identificación, aún cuando los tipos iconográficos se utilizan posteriormente en la representación de los apóstoles. El retrato de Sócrates de tipo silénico, como anciano calvo y de poblada barba, se encuentra casi idéntico en el mosaico de los sabios de Apamea (vid. supra), con antecedentes en una pintura de Efeso del siglo I d.C., remontando el prototipo de todos ellos al modelo tradicional conocido en el arte griego que se ajusta perfectamente al descrito por los autores clásicos (Plat. Symp. 215 ss; Xen. Symp. II 19, V 5 y 7 ; Cic. de Fat. ch. 5; Sid. Apoll. epist. IX 9,14) ${ }^{50}$.

La presencia de la musa Calíope junto a los sabios podría explicarse por la filosofía neoplatónica, según la cual las musas presiden todos los banquetes de los filósofos y en particular los de los sabios (Plut. Banquete 21), y no es nada raro su presencia en un pavimento de la residencia perteneciente a un rico discípulo de la escuela platónica, ya que se designa «Platonikos» en inscripción de la la tercera estancia. La situación privilegiada en el centro del mosaico de la musa Calíope tanto en este pavimento como en el de Monnus de Trier, aquí junto a Homero e Ingenius (vid. infra), se explica por ser Calíope desde la época clásica la musa de la oratoria y de la poesía épica, ocupando el primer lugar entre las nueve como inspiradora de todas las ciencias, casi al mismo nivel que Apolo, y de ahí que Pitágoras la equipare con la Filosofía (Max. Tyr. VII 2,63). Según Hesíodo (theog. 79), Calíope es la musa que acompaña a los reyes, dándoles la elocuencia necesaria para gobernar y conducir a sus pueblos.

Los siete sabios que acompañan a Sócrates corresponden a la lista más habitual de sabios, popularizada ya a mediados del siglo IV a.C. por Demetrios de Falere (Stob. III 79; XLIII 131), que sustituyó a la nómina dada por Platón en el siglo $\mathrm{V}$ a.C., quien incluía a Misón de Chénai en lugar de Períandro de Corinto. La lista de Demetrios fué aceptada por los autores de época posterior, como Diógenes Laercio (de uitis I 40) y Clemente de Alejandría (Stromata 114). Pítaco se cita entre los siete sabios en testimonios tardíos, como en el Ludus Septem Sapientum de Ausonio, del año 390 d.C. (Lib. XIII, IX, 202-213) ${ }^{51}$. Y sin embargo el nombre de Sócrates no aparece incluido en la lista tradicional de los siete Sabios, sino que como anota G.M.A. Hanfmann, Sócrates no era uno de los siete sabios, sino añadido a ellos, como en la Historia de los Filósofos de Porfirio donde Sócrates era aparentemente uno «del los siete que realmente eran nueve» (opuscula 4;

50 G.M.A. RICHTER, The Protraits of the Greeks, London 1965, I, 109-119, figs. 456-573.

51 Ed. Loeb Classical Library I, 326-327. Pítaco fué nombrado árbitro de la situación (aisymnétes) en la revuelta de Mitilene para actuar como una especie de dictador sobre las facciones enfrentadas. 
de abst. I 15, p. 54), o en Libanio (de Socr. sil. 9) donde Sócrates es el octavo sabio, incluyéndose junto a los siete a Heráclito y Pitágoras ${ }^{52}$. A pesar de ello, la presencia de Sócrates presidiendo el banquete (simposion) de los sabios se documenta también en el mosaico de Apamea (vid. supra), aunque en este último los sabios representados son seis y no siete; y combinado con algunos de los siete sabios aparece igualmente en otras escenas del arte romano, como en el sarcófago de las musas de Murcia, fechado en el último tercio del siglo III d.C., donde Sócrates está representado junto a Homero, Pitágoras, Hesíodo y tal vez Platón ${ }^{53}$. Y es que Sócrates presidiendo el Banquete de los Sabios de la Grecia Antigua es el Sócrates de la tradición neoplatónica, de Porfirio (de abst. I 15) y de Libanio (de Socr. sil. 9), al que el oráculo de la Pythia hacía «el más sabio de todos los hombres» (Porf. vit. Plot. 22,5; Diog. Laert. II 5,18).

Otro ejemplo de esta modalidad iconográfica lo contituye el mosaico de Colonia, conservado en el Römisch-Germanisches Museum, del tercer cuarto del siglo III, con la representación de los bustos de siete filósofos griegos dentro de hexágonos, acompañados de sus nombres escritos en griego ${ }^{54}$. En el centro figura Diógenes dentro de un círculo rodeado de dos grupos de tres bustos; a la derecha se disponen Platón, Sócrates y Cleóboulos; a la izquierda Quilón, Aristóteles y Sófocles. Ninguno de ellos sigue el modelo tradicional utilizado desde época clásica para la representación de estos sabios, separándose mucho de los tipos iconográficos que aparecen en otros pavimentos musivos: Sócrates en Baalbeck y Apamea; Cleóbulos en Baalbeck, Mérida y Nerodimjle; Quilón en Baalbeck, Apamea, Roma, Mérida y Nerodimjle. Es interesante hacer constar que este mosaico se halló cerca del pavimento dionisiaco, constituyendo un ejemplo más de la relación entre las representaciones de sabios y los temas báquicos (vid. infra).

Una variante ya tardía de este tipo de representaciones de grupos de sabios lo constituye el mosaico procedente de la villa o palacio serbio de Nerodimjle (Fig. 21), fechado a comienzos de época bizantina, donde pavimentaba una habitación absidada, con piscina circular en el centro, decorada con frescos y mosaicos. Destaca el panel con la representación de los siete sabios canónicos de la antigüedad, figurados como hombres

52 G.M.A. HANFMANN, Socrates and Christ, Harvard Studies in Classical Philology 60, 1951, 228, n. 43.

53 A. Garcia y Bellido, Esculturas romanas de España y Portugal, Madrid 1949, 230, $n^{\circ} 255$, láms. 189-190.

54 K. PARLASCA, Die römischen Mosaiken in Deutschland, 1959, 80-82, Taff. 80-82 


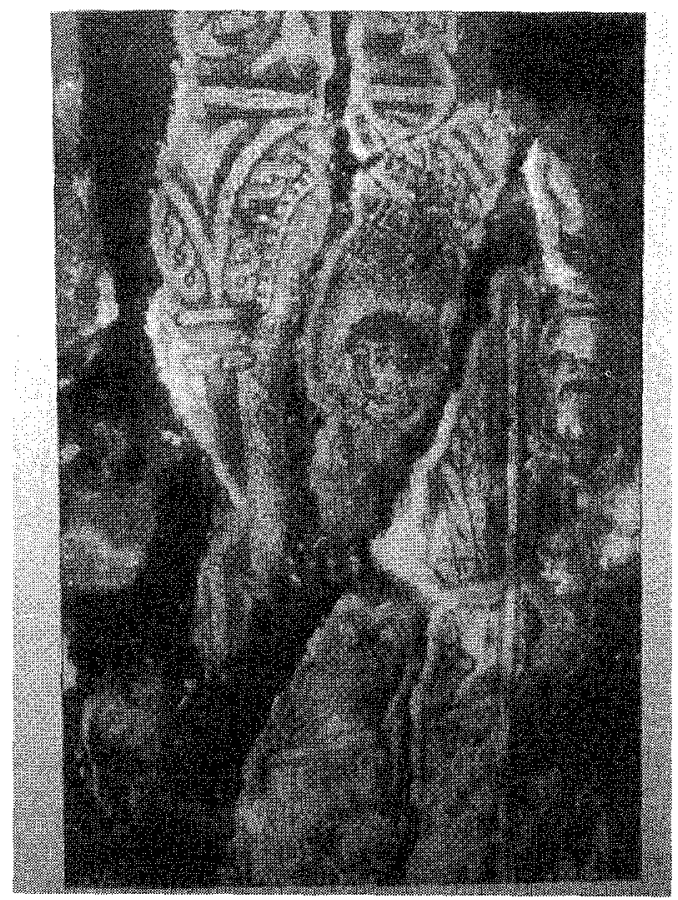

Figura 21. Mosaico de Nerodimile. Quilón.

jóvenes, en pie dentro de arquerías sobre columnas y vestidos con larga túnica y pallium. Debajo de cada uno de ellos hay una inscripción en latín con su nombre y proverbio: Pittacus Lesbius. Agnosce te ipsum; Solon Atheniensis. Ne quid nimis; Tales Milesius (falta la sentencia); Bias Prieneus. Plures malis; Cleobulus Myndius. Omnis mensura utilis; Periandrus Corintius. Sponde ...ui tibi malum; y Chilon Lacedemonius. Tempus agnosce. Existe un error de escritura en la inscripción correspondiente a Cleóbulo, que aquí aparece acompañado de Myndius en lugar de Lindius. Lo más interesante de esta composición son las estrechas analogías que presenta con los sarcófagos de columnas paleocristianos, en donde Cristo y los Apóstoles están igualmente dispuestos dentro de arquerías, evidenciando su influencia ${ }^{55}$. S. Djuric fecha este pavimento, por su estilo e iconografía, en el siglo VI y más concretamente en época de

55 G. Rodenwaldt, Säulensarkophage, MDAl XXXVIII-XXXIX, 1-2, 1923-1924, 1-40; G. KochH. Sichtermann, Römische Sarkophage, München 1982, 76-80, 503-507. 
Justiniano, constituyendo un ejemplo típico de la ambigüedad de la época al reflejar el renacimiento del clasicismo o la reacción pagana a la ortodoxia oficial ${ }^{56}$.

Otras veces los retratos de los sabios, en forma de bustos acompañados de sus nombres y en ocasiones también de las musas, se disponen alrededor del cuadro central, confiriendo un caracter filosófico a la escena mitológica alí representada, cuyo contenido alegórico también se halla en relación con el concepto abstracto de la ciencia o de la sabiduría. Ejemplos de esta modalidad lo constituyen el mosaico tardío de Seleucia de Pamphilia y el de Gerasa, datado a mediados del siglo III.

El mosaico de Seleucia de Pamphylia, conservado en el Museo Arqueológico de Antalya (Turquía), es un gran pavimento de forma cuadrada, cuya orla está integrada por 16 recuadros con bustos de griegos ilustres acompañados de sus correspondientes letreros en griego. En el lado derecho se encuentran bien conservados los bustos de Solón y Tucídides, mientras que de Herodoto solo queda el nombre. La zona superior está ocupada por los retratos de Ferécidas, Demóstenes, Heráclito, del que resta la parte derecha de la cabeza, Hesíodo y Licurgo. En el extremo inferior derecho se aprecian restos del busto de Jenofonte y en el lateral izquierdo se conservan en bastante buen estado los de Anaxágoras y Pitágoras que fué el primer mortal heroizado por su ciencia, por los méritos de su inteligencia. Del emblema solo queda una lanza y los nombres de Homero en el centro, llías a la derecha y Odisea a su izquierda, es decir el autor va acompañado de las personificaciones de la llíada y la Odisea ${ }^{57}$.

Representaciones individualizadas de sabios en forma de bustos, acompañados de su nombre, se documentan en otros pavimentos. Tal es el caso del mosaico de la sala AB del triclinio de Apamea, fechado en el tercer cuarto del siglo IV, del que solo se ha conservado el busto de Quilón de Esparta; los dos fragmentos con los retratos de Solón y de Períandro, procedentes de la Casa de los Astros en Antioquía, que se fechan hacia el 400; el panel de Mitilene, de la misma fecha, con el retrato de Menandro; y el mosaico de Sbeitla, que se data a fines del siglo IV o a comienzos del $\mathrm{V}$, en el que se ha representado a Jenofonte.

56 S. Djuric, Mosaic of philosophers in an early byzantine villa at Nerodimjle, VI CIMA, Guadalajara 1994, 123 y ss.

57 J.M. Blázquez Martínez-G. López Monteagudo, Mosaicos de Asia Menor, AEspA 59, 1986, 237-238, figs. 6-7; R.R.R. Smith, Late Roman Philosopher Portraits from Aphrodisias, JRS LXXX, 1990, 151. 
El pavimento procedente de la sala $A B$ del llamado triclinio de Apamea, combina cuadros mitológicos y paisajes alejandrinos con cuatro bustos de los sabios, de los que únicamente se han conservado Quilón y Tales ${ }^{58}$. En el ángulo SE. de la habitación está representado Quilón de Esparta, acompañado de una inscripción en griego con su nombre: «Quilón de Lacedemonia», y su máxima: «Conócete a tí mismo». Está representado como un hombre maduro, con barba y se viste con pallium. Sus rasgos fisonómicos se aproximan de forma evidente al último de los sabios representados en el mosaico de Sócrates y los sabios procedente del edificio pagano debajo de la catedral de Apamea (vid. supra).

En 1987 fueron adquiridos por el Museo de Arte y de Historia de Ginebra a la antigua Colección Khoury de Beirut dos fragmentos de mosaico polícromo procedentes de la Casa de los Astros en Antioquía, fechados en torno al 400 , con los retratos de Solón y Períandro dentro de hexágonos acompañados de una inscripción con su nombre ${ }^{59}$. Los sabios están representados de tres cuartos, con mirada inquisidora, cabello corto y abundante barba; van vestidos a la manera de los filósofos, con pallium sobre el torso desnudo.

Del triclinium de la Casa de Menandro, en Mitilene, procede un panel cuadrangular con representación de un busto masculino acompañado de una inscripción en griego con su nombre: Menandro. Va vestido con túnica y lleva el pallium de los doctores, peina el cabello a mechones hacia la parte delantera de la cabeza, sin cubrir la frente que aparece surcada por grandes arrugas al igual que las mejillas. Los ojos presentan un ligero estrabismo y todos sus rasgos fisonómicos se corresponden con la tradición literaria (Athen. VI 248 d y VIII 264d; Phed. Fab. Aesop. V 1, 12 ss.), dando a entender que estamos en presencia de un verdadero retrato y no de una representación idealizada. Otros retratos del poeta se documentan en los mosaicos de Trier, Antioquía y posiblemente en Thuburbo Maius. Datado en el 300 por S. Charitonidis y en el 400 por L. Berczelly ${ }^{60}$.

El pavimento procedente del ábside del oecus del llamado «edificio de las estaciones" en la antigua Sufetula, Sbeitla, conservado en el Museo de

58 J. BALTRY, Une nouvelle mosaïque du IVe s. dans l'edifique dit "au triclinos" à Apamée, Annales Archeologiques arabes syriennes XX, 1970, 81 ss.

59 Inv. núms. 26108 y 26109 , cf. Acquisitions du Musée d'art et d'histoire en 1987, Genava 36 n.s., $1988,204$.

60 S. Chatitonidis-L. Kahil-R. Ginouves, Les mosaïques de la Maison de Ménandre à Mytilène, 1970, 27-31, pl. 2 y 15; L. BERCzELL.Y. The Date and Significance of the Menander Mosaics at Mytilene, BICS 35, 1988, 119-126. 
El Bardo, contiene seis paneles alineados horizontalmente y todos presumiblemente acompañados de inscripciones. Los cuatro cuadrados centrales, decorados con figuras masculinas de jóvenes representando a las estaciones, van flanqueados por dos medallones con retratos en forma de busto. Solo se ha conservado el retrato del extremo derecho, en forma de imago clipeata, acompañado de la inscripción «Autor Xenofonta». El personaje está visto de tres cuartos con la mirada levantada ligeramente hacia su derecha; tiene el cabello y la barba de color gris y viste túnica roja con pallium negro sobre el hombro izquierdo. Entre las varias posibilidades de identificación que se han propuesto para el busto, nos parece la más acertada la de D. Parrish que lo relaciona con un «autor» o «escritor» y concretamente con el célebre autor griego Jenofonte, aunque el artista no ha seguido un modelo específico sino que ha utilizado un tipo genérico de filósofo o de poeta. La asociación de los intelectuales con las estaciones, que se constata en otros mosaicos romanos: Baalbeck, Gerasa, Palermo, mosaico de Monnus en Trier y Sfax, tiene el sentido según Parrish de proveer de dignidad cósmica a los retratados. Este autor, basándose en criterios estilísticos, propone una fecha a fines del siglo IV o comienzos del $\mathrm{V}{ }^{61}$.

El mosaico dionisiaco de Gerasa, descubierto a comienzos del siglo en una casa de la zona oriental de la ciudad antigua y conservado en parte en el Pergamonmuseum de Berlín, en el Stark Museum of Art de Orange (Texas) y en la embajada de España en Damasco, ofrece una orla en la que están representados alternativamente los sabios y las Musas identificados por sus nombres en griego: Tucídides, Homero (Fig. 22), Olimpos, Alcman, Stesícoro y quizás Anacreonte, Urania, Calíope, Clío, Euterpe, Tersícore, Erato y tal vez Melpomene, enlazados por guirnaldas que sostienen putti ${ }^{62}$. El tipo emocional de Tucídides figurado en este mosaico no coincide con las descripciones hechas por los historiadores ni con la iconografía escultórica. Homero está representado siguiendo los modelos clásicos, que responden a la descripción hecha por Christodoros (Ecphr., en Gk. Anth. II 322 ss.) como hombre de aspecto venerable equiparable a Zeus, con un paralelo muy próximo en un panel vidriado procedente del

61 D. PARRISH, Season Mosaics of Roman North Atrica, Roma 1984, 215-218, PI. 76; Id., The Mosaic of Xenophon and the Seasons from Sbeitla (Tunisia), Mosaïque. Recueil d'hommages à $H$. Stern, Paris, 1983,297 y ss.

62 C.H. Kraeling, Gerasa. City of the Decapolis, New Haven 1938, 351 y sS., PI. LXXXV,b); H. JoYCE, A Mosaic from Gerasa in Orange, Texas, and Berlin, $R M$ 87, 1980, 307 y ss.; E. THEOPHILIDOU, Die Musenmosaiken der römischen Kaiserzeit, TZ 47, 1984, 264-266.; I. KRISELEIT, Antike Mosaiken. Staat/iche Museen zu Beriin, Rostock 1985, 18-21, 66-68; M. PICcIRILLo, Mosaici della provincia Arabia, en / Mosaici di Giordania, Roma 1986, 32. 


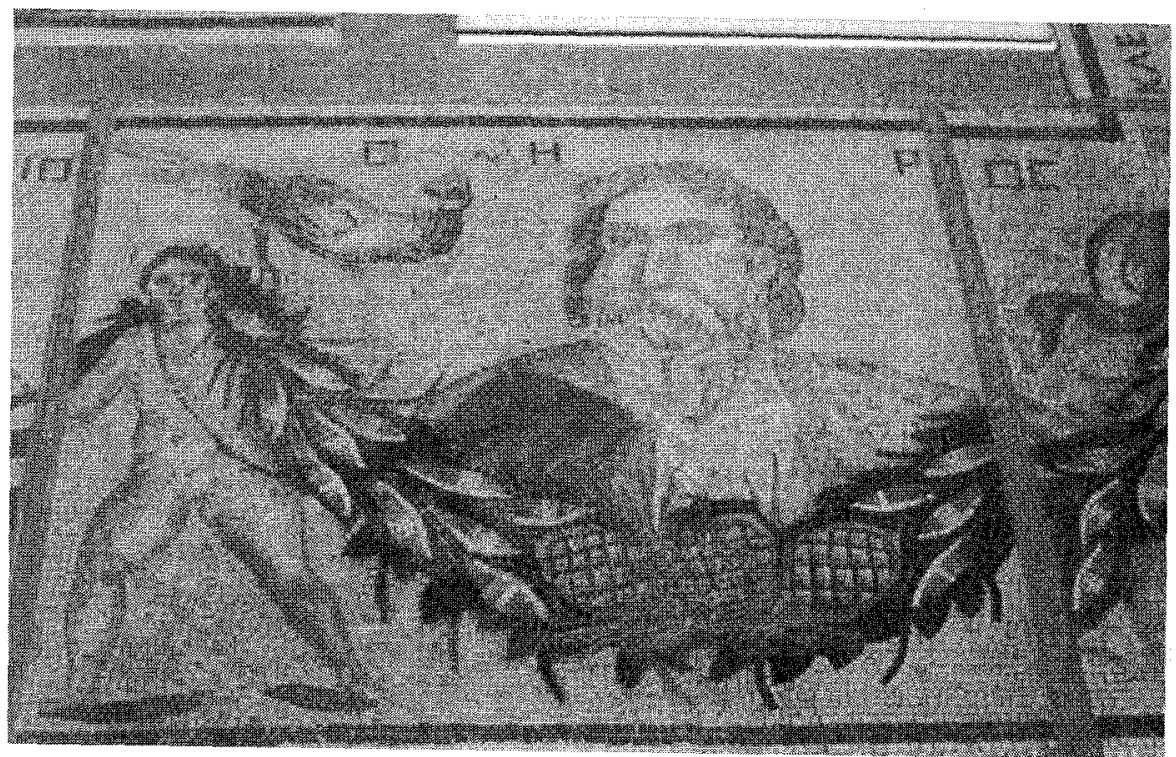

Figura 22. Mosaico de Gerasa. Homero. (Foto G. López Monteagudo).

puerto de Corinto, fechado en el 250 d.C., donde está representado de cuerpo entero ${ }^{63}$.

El deseo de alcanzar la sabiduría suprema mediante la cultura explicaría el éxito del culto a las Musas en la cultura romana tardía y su frecuente asociación con temas dionisiacos sobre todo en los sarcófagos y en algunos mosaicos, como los de Cos II, Gerasa, Colonia, Antioquía y Torre de Palma, ya que según R. Turcan, Dionisos es cantado por los poetas griegos como el Cosmokrator que dispensa a la oikoumené la vida civilizada; y esa figura helenística del héroe colonizador, vencedor de las fuerzas brutas y desordenadas del mal, aureolado del prestigio reconocido en la virtus del héroe civilizador, es retomada en época romana con gran éxito, hasta el punto de que para la misma figura de Sileno se adopta el tipo socrático de hombre maduro, imagen de la sabiduría y del equilibrio interior, con torso desnudo, manto blanco, frente despejada, barba abundante y bastón de filósofo, como personificación de la cultura filosófica en

63 G.M.A. RICHTER, The Portraits of the Greeks, London 1965, I, 45 y ss. y 147 y ss.; Kencherai II, Leiden 1976, 168-174, Figs. 32, 139-146, panel VI.3.A. 
su calidad de pedagogo de Dionisos ${ }^{64}$. H. Joyce explica la asociación entre las musas y las escenas dionisiacas por ser Dionisos una divinidad estrechamente conectada al teatro y en ese contexto el dios era un compañero frecuente de las Musas ${ }^{65}$.

Al parecer, la divulgación del tema del diálogo entre los Sabios y las Musas tiene lugar a través de la producción de sarcófagos en el siglo III d.C. ${ }^{66}$, documentándose con relativa frecuencia en mosaicos de los siglos III y IV , como consecuencia de la filosofía neoplatónica según la cual las musas presiden los banquetes de los filósofos y en especial los de sabios (Plut. Banquete 21). Ya Platón (Banq. 187 e) colocaba bajo el patronazgo de Urania y de Polimnia todas las manifestaciones de la actividad cultural, la primera como inspiradora de las formas superiores y la segunda de las formas vulgares del amor. Se ha supuesto que la relación de las musas con los sabios o filósofos tiene que ver con la inspiración de que son objeto por parte de cada una de ellas: la filosofía, la literatura, la poesía, la música, las matemáticas, la geometría o la astronomía. Sin embargo, según Plutarco el «objeto» de las musas no es la cítara o la flauta, sino "la educación de las costumbres y el dominio de las pasiones a través de sus cantos armoniosos», en suma, la cultura o Mousiké ${ }^{67}$. Para Martianus Capella, filólologo africano del siglo $\mathrm{V}$ d.C., la esperanza de alcanzar la inmortalidad a través del conocimiento total de las ciencias, de las nueve disciplinas enciclopédicas que patrocinan las Musas, es la que se encuentra en la religión de las musas tal como proclama Talía al final de los cantos por los cuales cada musa invita a la Filología a recorrer sin ausentarse las nueve órbitas celestes (2, 126). La religión de las musas, que es la de los filólogos, abre las puertas del cielo a los mortales porque es a la vez sabiduría y elocuencia, dispensadora del saber y también de la gloria dada por la inmortalidad. El concepto de la heroización por la ciencia, ligado al culto de las Musas, nace con el pitagorismo y se extiende a todo el pensamiento griego: Platón, Plotino, Aristóteles, Epicuro, Metrodoro, han participado de esta

\footnotetext{
64 R. TuRCAN, Les sarcophages romains à représentations dionysiaques, Paris 1966, 441 y ss.

65 H. JorCE, A Mosaic from Gerasa in Orange, Texas, and Berlin, $R M$ 87, 1980, 319 y ss.; E. THEOPHILIDOU, Die Musenmosaiken der römischen Kaiserzeit, $T Z$ 47, 1984, 239 y ss.

66 La representación de filósofos en los sarcófagos demuestra la vinculación del sabio o del filósofo con la vida de ultratumba, dentro de la clase dirigente del imperio, cf. H.I. MArrou, MOYCIKOC ANHP. Etude sur les scènes de la vie intellectuelle figurant sur les monuments funéraires romaines, Roma 1964, 209 y ss.

67 Plutarco, Le Banquet des Sept Sages. Texte, traduction avec une introduction et de notes, por J. Defradas, Paris 1954, 64-65.
} 
creencia ${ }^{68}$. La confirmación a los textos se encuentra p.e. en el pavimento de Baccano, datado a comienzos del siglo III, en el que se combinan las figuras de las Musas con escenas del mito de Ulises, como símbolos de la ciencia y la inteligencia contrapuestas a la ferocidad o incultura escenificadas en la lucha de Eros y Pan y el suplicio de Marsias, y todo ello inserto en una visión cósmica a través de los motivos marinos y las estaciones ${ }^{69}$.

Además de los citados mosaicos de Baalbeck y de Gerasa, las representaciones de sabios en compañía de las musas abundan en la musivaria de todo el imperio, como se comprueba en los ejemplares siguientes procedentes de Antioquía, Grecia, Norte de Africa, Hispania, Italia y Germania.

En el emblema del mosaico procedente de la Casa de Menandro (Fig. 23), habitación 11, en Antioquía, conservado en la actualidad en el Museo de Arte de la Universidad de Princeton, se representa a Menandro junto a Glicera, su musa, y Comoidia, todos acompañados de su nombre escrito

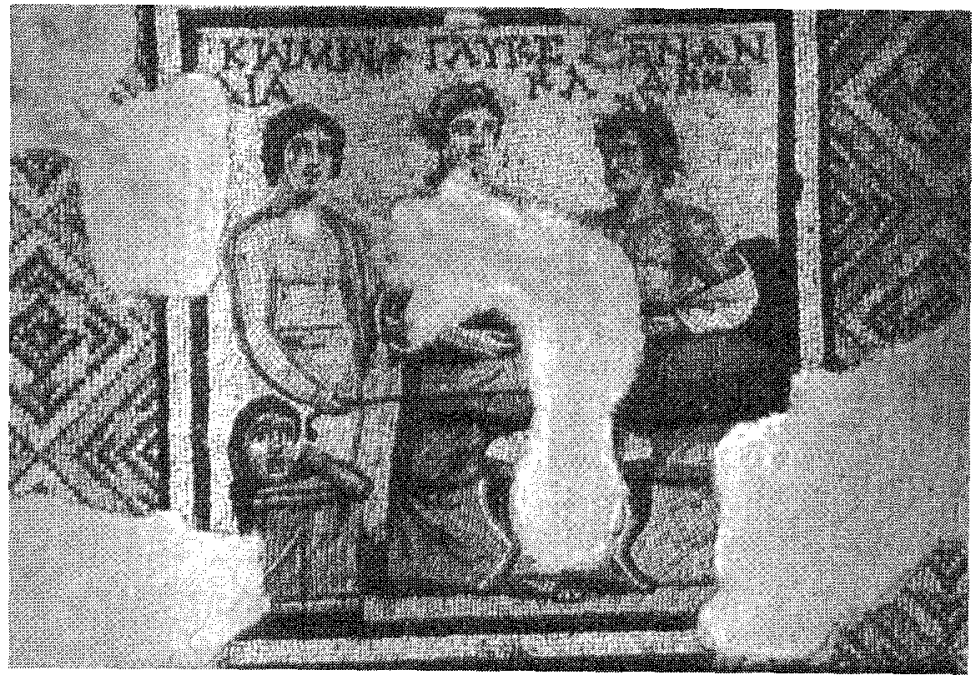

Figura 23. Mosaico de la Casa de Menandro en Antioquía.

68 F. Cumont, After-Life in Roman Paganism, New-Haven 1922; P. Boyancé, Le culte des Muses chez les philosphes grecs, Paris 1993, 231 y ss.; J. PrÉAux, Le culte des Muses chez Martianus Capella, Mélanges P. Boyancé, Roma 1974, 610-611.

69 Cf. L. Paduano Faedo, I sarcofagi romani con muse, ANRW \|l 12.2, 1981, 72, n. 12. 
en griego. Glicera y Menandro aparecen recostados en una kliné, mientras que la figura de la Comedia está en pie sosteniendo en la mano izquierda una máscara y en la derecha un puntero que dirige hacia la mesa situada en el centro. Se fecha a comienzos del siglo III d.C. ${ }^{70}$.

El pavimento de Esparta, procedente del atrio de una gran casa y conservado en el Museo Arqueológico de Esparta, se halla muy fragmentado. En el panel central, de forma rectangular, estaban representadas las nueve Musas de las que solo se conservan, identificadas por inscripciones, Urania sosteniendo el globo celeste, Calíope y parte del nombre de Polimnia. Rodeando el emblema en tres de los lados se disponen paneles cuadrados que alternan motivos geométricos y cinco retratos en forma de busto, cuatro de ellos correspondientes a los poetas griegos Safo, Alcman y Anacreonte y al político Alcibiades, acompañados de los rótulos con sus nombres, así como otro busto masculino cuya inscripción se ha perdido pero que tal vez puede identificarse con Alkaios. Junto a esta serie de paneles había otras escenas figuradas que incluían las personificaciones del Día y la Noche con sus rótulos, la figura anepígrafa de Helios y probablemente la de Selene, hoy perdida. Se fecha a fines del siglo III o comienzos del IV ${ }^{71}$.

Una composición en la que también parecen intervenir sabios y musas se documenta en el pavimento hispano de Torralba. El mosaico, muy deteriorado, presenta una escena de filosofía o de musas, de identificación problemática por haberse conservado solamente restos de tres personajes femeninos y de uno masculino. De izquierda a derecha existen primero restos de una figura femenina; a continuación otra figura femenina, de la que se conserva la cabeza y parte del cuerpo; el busto aparece atravesado en diagonal por el pliegue de la palla. Entre esta figura y la siguiente hay un espacio en blanco que puede corresponder a la lira citada en la descripción de M. Gómez Moreno. La tercera figura también es femenina y de ella se conserva parte de la cabeza y la mitad longitudinal izquierda del cuerpo. En un primer plano y delante de esta última aparece un personaje masculino del que solo se conserva parte del cuerpo, vestido con túnica

70 R. STILLWELL, Antioch on-the-Orontes III, Princeton 1941, 185-186, PI. 63; D. LEVI, Antioch Mosaic Pavements, Princeton 1947, 201-203, pl. XLV c. En el momento de su descubrimiento existía una laguna en esta zona del mosaico, posteriormente reconstruida, por lo que no es posible saber el tipo de objeto señalado por la figura de la Comedia.

$71 \mathrm{CH}$. Christou, Adelt 19, 1964, Chron. II.I, 138-141, pl. 138-140; G. Daux, BCH 90, 1966, 793, figs. 1-3; Hellenika 26, 1973, 249-250, n 65, pl. 29 b; S.E. WAYWELL, Roman Mosaics in Greece, AJA 83, 1979, 303; E. THEOPHILIDOU, Die Musenmosaiken der römischen Kaiserzeit, TZ $47,1984,254-258$. 
y pallium blanco; tiene el brazo derecho plegado, dejando el antebrazo y la mano visibles, apoyado sobre el pecho y recogiendo el borde superior del palio (Fig. 24). Se fecha en el siglo IV ${ }^{72}$.

El mosaico in situ, de mediados del siglo III d.C., que pavimenta una gran sala, probablemente de reunión, situada entre las termas y el teatro de Bulla Regia, va decorado con veinte medallones, once circulares y nueve cuadrados, de los que quedan dos bustos fragmentarios, uno masculino y otro femenino, quizás una musa, y restos de un ciervo y de una gacela. En el cuadrado exterior izquierdo de la cuarta fila se encuentra el busto de un hombre con manto, barba y bigote, que $E$. Theophilidou identifica como un «literato» o quizás como uno de los siete sabios si se admite que en los cuadrados y en los medallones están representados los siete sabios y las nueve musas ${ }^{73}$.

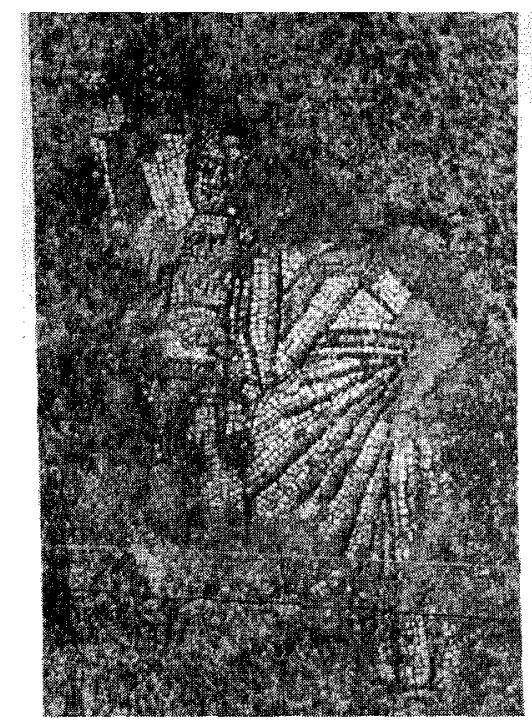

Figura 24. Mosaico de Torralba. Detalle.

72 M. Gómez Moreno, Miscelánea, Madrid 1949, 375; E. Pareja - M. Sotomayor, Excavaciones en el yacimiento romano de Torralba en Huéscar (Granada), NAH Arq. 6, 1979, 499-522, fig. 7, láms. VIla-b.

73 R. Hanoune, Une muse et un philosophe sur une mosaïque de Bulla Regia, Mélanges $P$. Boyancé, Roma 1974, 387-394, fig. 5; A. BEschaouch - R. Hanoune - Y. Thébert, Les ruines de Bulla Regia, Roma 1977, 111, fig. 111; E. THEOPHILIDOU, Die Musenmosaiken der römischen Kaiserzeit, TZ 47, 1984, 316-317. 
El llamado mosaico de los «Literatos», procedente de Trier y conservado en el Rheinisches Landesmuseum, conjunta igualmente el tema de los sabios y las musas, aunque en escenas separadas. Solo ha llegado hasta nosotros la mitad del pavimento constituída por dos paneles yuxtapuestos, uno de mayor tamaño que ocuparía el centro del pavimento, está formado por un octógono central, casi perdido, en el que se ven las figuras de Mercurio con caduceo y Minerva, rodeado de cuadrados y hexágonos. De estos últimos se conserva uno decorado con dos musas sentadas en sillones de respaldo curvo (cathedrae), típicos de los sabios en otros pavimentos de Trier (vid. supra) y en los mosaicos de Sfax, Autun, Sousse y Palermo (vid. infra). Es de suponer que el resto de los hexágonos Ilevaría el mismo tipo de figuras agrupadas de dos en dos. Los dos cuadrados que se conservan van decorados con figuras masculinas de sabios o literatos en pie vestidos con el pallium; están representados en actitud declamatoria con la mano derecha levantada, uno de ellos sostiene un cálamo en la derecha y un dychticon en la izquierda, mientras que el otro lleva un rollo o volumen, iconografía que se repite en otro cuadro de este mosaico y en uno de los paneles de Autun donde se ha representado a Epicuro en actitud de discusión con la mano izquierda levantada (vid. infra). El panel lateral lo forman seis rectángulos, de los que solo se conservan tres ocupados cada uno por un personaje, vestidos también con el pallium pero, a diferencia de los anteriores, su actitud es más reposada y meditabunda (Fig. 25). Uno de ellos lleva bastón en la mano izquierda y en la derecha un puntero, pudiéndose identificar con Tales; el segundo, con la frente despejada y larga barba, dobla el brazo derecho en posición de orador, tal vez podría identificarse con Sócrates; el último junta sus manos en actitud pensativa recordando los retratos de Demóstenes o la figura de Platón identificada por su nombre en un panel de vidrio de Kencherai (Fig. 26), puerto de Corinto, del 350 d.C. ${ }^{74}$. K. Parlasca fecha este pavimento en el 200 , mientras que $\mathrm{E}$. Theophilidou se inclina por el $250^{75}$.

Una variante muy característica de este tipo de composiciones, en las que intervienen los sabios y las musas, es el grupo formado por un sabio generalmente sentado en compañía de una o dos musas, que se encuentran a su lado en pie.

\footnotetext{
74 G.M.A. RICHTER, The Portraits of the Greeks, London 1965, II, 215 y ss; Kencherai II, Leiden 1976, 175-178, Figs. 33, 147-152, panel VI.3.B.

75 K. Parlasca, Die römischen Mosaiken in Deutschland, 1959, 27-28, Taff. 26-27; E. THEOPHILIDOU, Die Musenmosaiken der römischen Kaiserzeit, TZ 47, 1984, 278-279.
} 


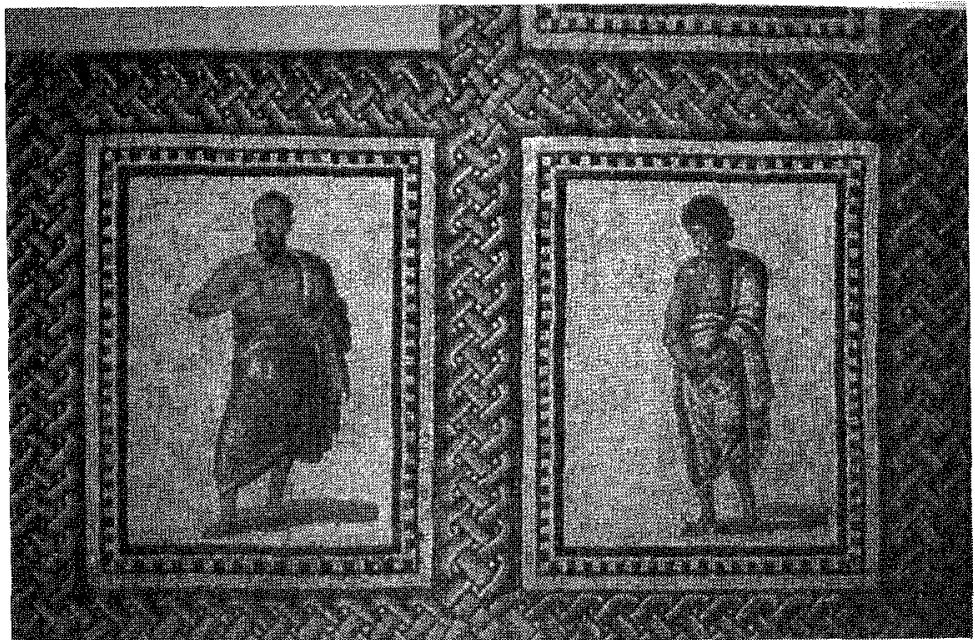

Figura 25. Mosaico de los «literatos» de Trier. (Foto G. López Monteagudo).

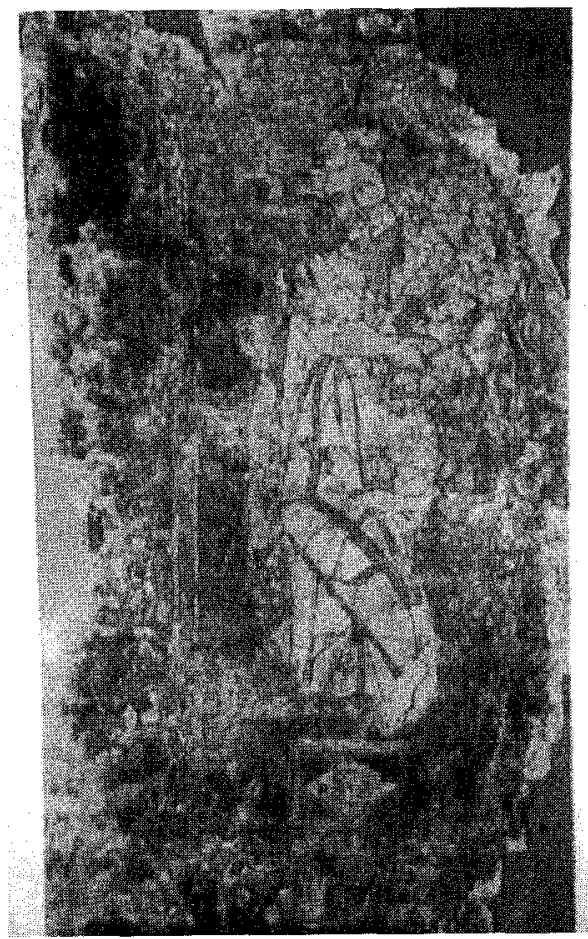

Figura 26. Panel vidriado de Kencherai. Platón. 
En el conocido mosaico de Virgilio (Fig. 27) procedente de la Casa del Arsenal (Casa de Virgilio) en Hadrumetum, Sousse, actualmente en el Museo de El Bardo, el poeta aparece sentado en una «cátedra» y con los pies sobre una especie de escaño o cojín; va vestido con túnica adornada con clavi y se cubre con el pallium; en la mano izquierda sostiene sobre su rodilla un volumen desplegado en el que se leen las palabras de uno de los versos de la Eneida (Aen. I 8): Musa mihi causas memora quo numine laeso Quidve..., escogidas para enfatizar, según Dunbabin, la divina inspiración representada por las musas Melpomene y Clío, que le acompañan en pie una a cada lado del poeta. Se fecha a comienzos del siglo III d.C. y concretamente en 200-210 ${ }^{76}$. Iconográficamente la figura de Virgilio presenta un gran paralelismo con la del poeta del Virgilio Romano (Vat. lat. 3867 ; fol. 3), datado en los siglos V-VI d.C., donde se le representa solo, sentado de frente en un sillón, con los pies sobre un escaño y vestido con túnica y manto; sostiene con ambas manos un rollo; a la derecha se ha situado un atril y a la izquierda la capsa (Fig. 28) ${ }^{77}$.

El grupo iconográfico del poeta acompañado de dos musas se vuelve a encontrar en el gran mosaico de Roma, descubierto a fines del siglo XVIII en Tenuta di Porcareccia, lugar identificado con Lorium, y trasladado al Vaticano. Se fecha en la primera mitad del siglo III d.C. El pavimento, que

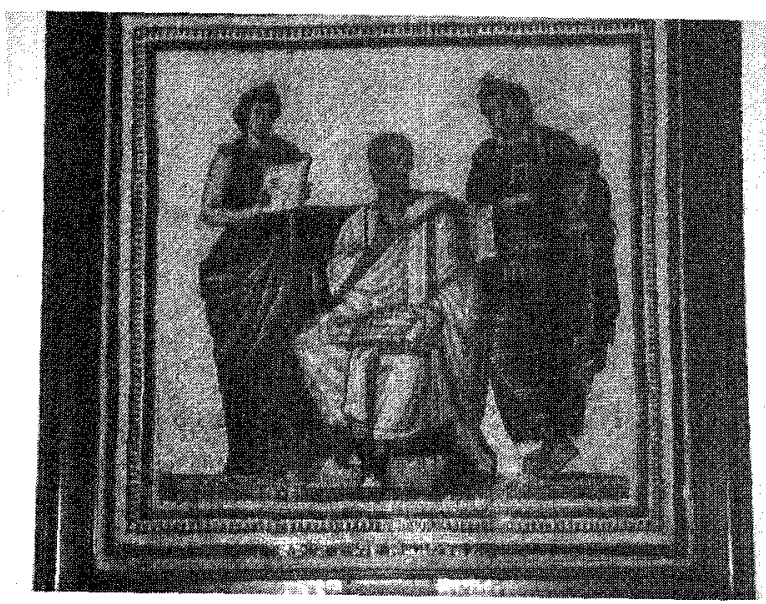

Figura 27. Mosaico de Virgilio de Sousse. (Foto G. López Monteagudo).

76 K.M.D. Dunbabin, The Mosaics of Roman North Africa, Oxford 1978, 131, 242, 269.

${ }^{77}$ Cf. Biblioteca Apostólica Vaticana, Madrid 1987, 42, lám. Ill. 


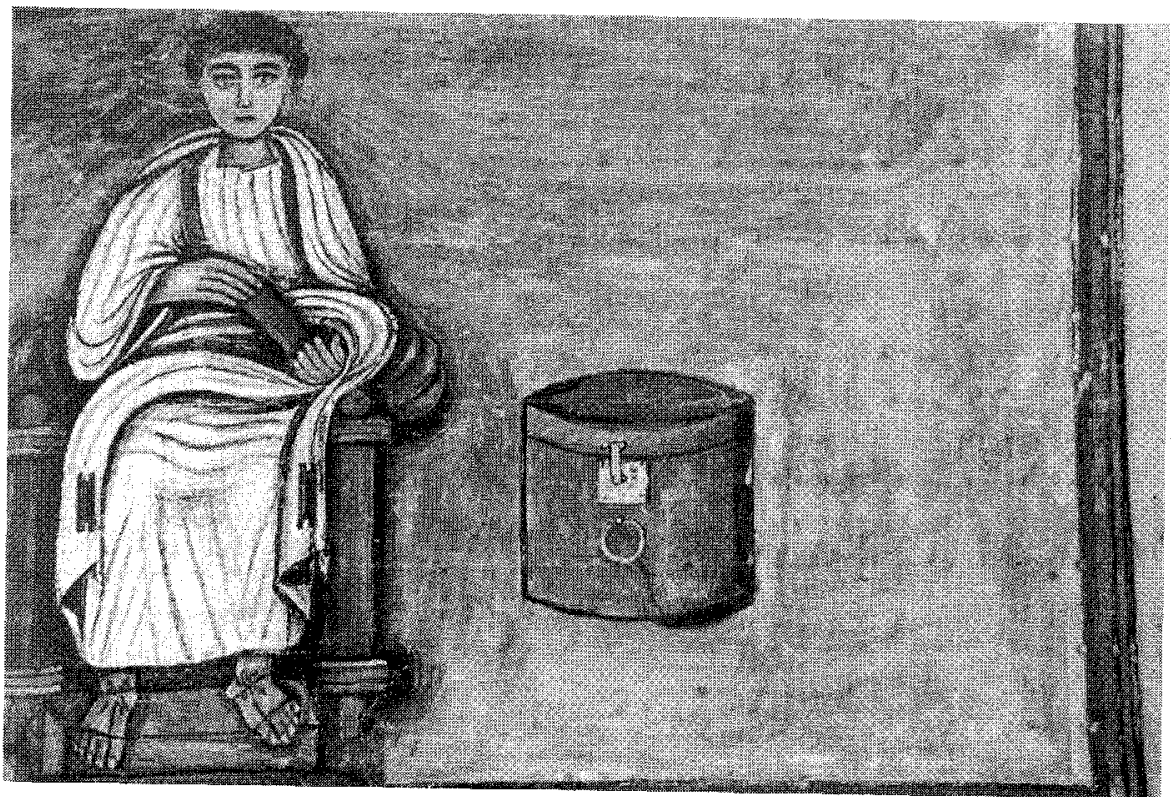

Figura 28. Virgilio Romano (Vat. lat. 3867; fol. 3).

cubría una sala de forma octogonal, presenta una composición a base de 24 hexágonos decorados con escenas del teatro. En uno de ellos aparece un joven poeta sentado hacia la derecha, tal vez Ennius o Menandro, al que un pequeño personaje presenta dos máscaras; lleva corona vegetal y viste un amplio manto que le cubre el hombro izquierdo y deja libre el derecho y el torso, como los personajes representados en los mosaicos de Torre Annunziata (vid. supra), del Aventino de Roma, de Thuburbo Maius y de Autun (vid. infra); sostiene una larga vara en la mano izquierda. A sus espaldas se encuentran en pie dos musas, una con máscara que se identifica con Melpomene y la otra sin atributo, podría ser Polimnia ${ }^{78}$. Otros mosaicos donde se representan las máscaras junto a los literatos son los de Mérida, Arróniz, Trier, Sousse, Thuburbo Maius, Palermo y Cartago (vid. infra). La misma composición, en la que intervienen un poeta, musas y actores, se atestigua en pinturas de Pompeya y Herculano ${ }^{79}$.

78 A.L. Millin, Description d'une mosaïque antique au Musée Pio-Clémentin à Rome représentant des scènes des Tragédies, 1829; B. NoGARA, I mosaici antichi conservati nei Palazzi Pontifici del Vaticano e del Laterano, 1910, 27-32, pl. LVI-LXVI; E. THEOPHILIDOU, Die Musenmosaiken der römischen Kaiserzeit, $T Z$ 47, 1984, 270-271.

79 S. ReINACH, RPGR, Paris 1922, 310,7;314,1. 
Parecida composición, aunque esta vez formada por literato acompañado de una sola musa, se vuelve a encontrar en el mosaico de Sfax, de mediados del siglo III, en los pavimentos hispanos de Mérida y Valencia, fechados a fines del siglo II, en el de Arróniz, de baja época, así como en el de Trier de la primera mitad del siglo III, documentándose en compañía de un actor en el mosaico de Sousse, con una cronología de comienzos del siglo III.

En el mosaico de las Musas de Sfax, procedente de Taparura y conservado en el Museo de Sfax, la composición muestra ocho círculos entrelazados con las figuras de las musas acompañadas de sus atributos, pudiéndose identificar a Clío con el dyptichon, Terpsícore con la lira, Erato llevando la cítara, Talía con pedum y máscara, Polimnia o Calíope sin atributo y Urania con el globo y el radius. Los bustos de las estaciones decoran las esquinas. En el medallón central (Fig. 29) se representa a un filósofo o literato sentado en una "cátedra», con una capsa a sus pies y sosteniendo dos volumina. Va vestido con túnica, adornada con clavi, y manto sobre el hombro izquierdo. Le acompaña una musa que se halla en pie a sus espaldas. Ambos personajes se han identificado como el poeta Ennius y la musa Clío, aunque también podría tratarse de un filósofo o escritor y de la musa Polimnia, Calíope, Euterpe o Melpomene. Se fecha a mediados del siglo III ${ }^{80}$.

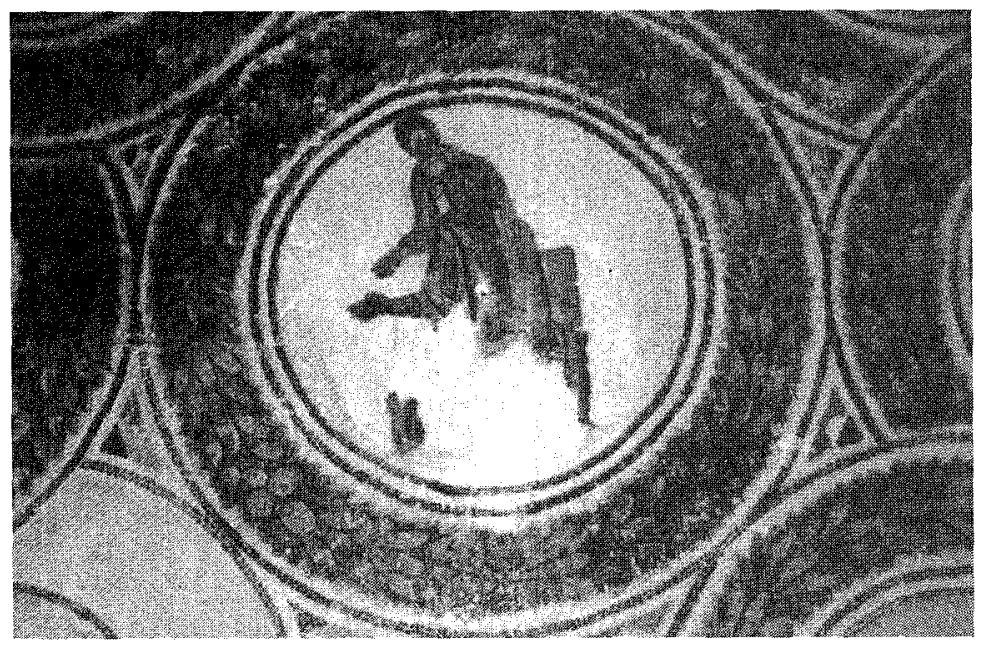

Figura 29. Mosaico de Sfax. Emblema. (Foto G. López Monteagudo).

80 D. PARRISH, Season Mosaics of Roman North Africa, Roma 1984, 218-221, PI. 77-78; E. THEOPHILIDOU, Die Musenmosaiken der römischen Kaiserzeit, TZ 47, 1984, 326-329. 
En Mérida se descubrió en el siglo pasado un mosaico de esquema a compás (Fig. 30), firmado por Seleucus y Anthus, que se fecha a finales del siglo Il y se conserva en el Museo de Arte Romano de Mérida ${ }^{81}$. En el medallón central se ha representado una figura varonil sentada, con cayado en la mano derecha y máscara en la izquierda, que adorna su cabeza con corona vegetal, en compañía de una musa, tal vez Erato, que aparece de pie sosteniendo la cítara y el plectro, y de una cabra. El poeta ha sido identificado por A. Blanco como Teócrito, padre de la poesía bucólica. Las ocho restantes musas ocupan los cuartos de círculo en grupos de dos, identificándose con seguridad a Urania por la esfera y el puntero que lleva en las manos. En los ángulos de la cenefa, decorada con escenas nilóticas, se han representado dos figuras de sabios en pie, uno con máscara identificable con alguno de los poetas célebres, tal vez Moschos o Bíos, y el otro señalando con un puntero a una esfera colocada sobre un trípode, que bien podría ser Tales por ser este sabio al que se atribuye la invención de la primera esfera celeste, la esfera llena que llevaría en su

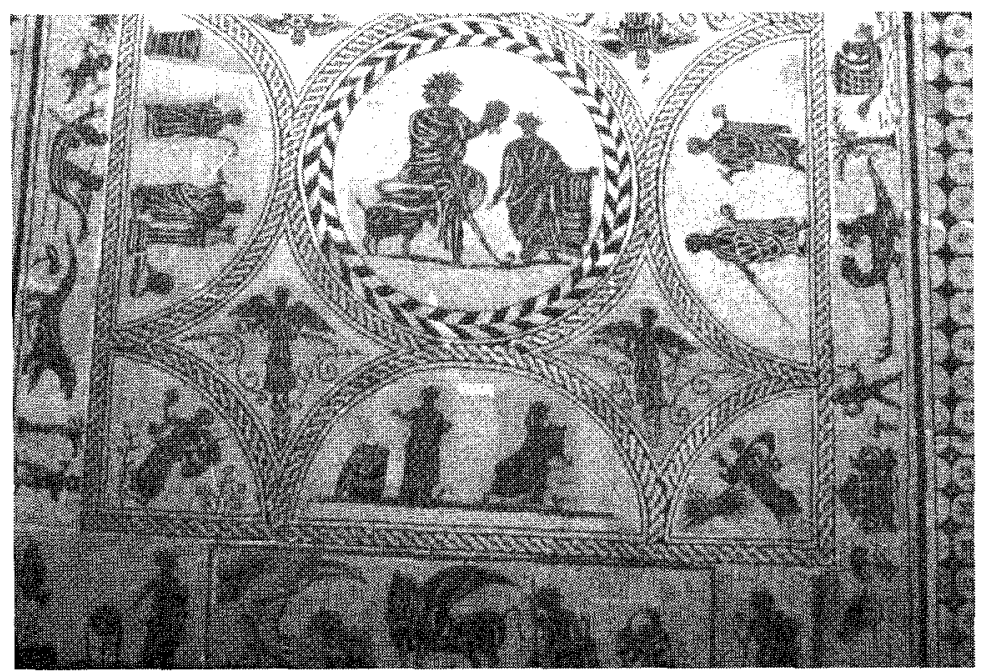

Figura 30. Mosaico de Mérida. (Foto cortesía J. M. Alvarez Martínez).

81 A. Blanco Freijeiro, Mosaicos romanos de Mérida, CME I, Madrid 1978, 30-32, láms. 1220. Aunque el pavimento sufrió muchos destrozos durante su levantamiento; los dibujos realizados por A.M. Carril y M. Albo permiten conocer el contenido de las zonas que faltan, en especial el medallón central. 
superficie los cinco círculos que dividen el cielo (Cic. Rep. I 14,22). También podría tratarse de Arato, célebre autor del poema Phaenomena, representado seguramente en una copa de plata de la Biblioteca Nacional de Paris y que aparece en el pavimento de Trier junto a una esfera y la musa Urania, identificados ambos por sus nombres (vid. infra). O tal vez de Pitágoras representado, sentado o de pie delante de la esfera colocada sobre un pedestal a la que señala con un puntero, en monedas de bronce de época imperial emitidas en Samos (Fig. 31) ${ }^{82}$.

En fechas recientes se ha descubierto en Valencia un mosaico muy fragmentario, datado a fines del siglo II, en cuyo emblema circular se representa una musa que sostiene en la mano izquierda una lira apoyada en un alto pedestal, acompañada de un personaje masculino del que solo se conservan los hombros y la barbilla. Debajo de las figuras aparecen restos de una inscripción, que los autores interpretan como Tersipchoreon, haciendo referencia al destino musical de la habitación. Sin embargo, J. Gómez Pallarès se inclina por el simple nombre de la musa: Tersícore ${ }^{83}$.

El mosaico de Arróniz (Fig. 32), que se conserva en el Museo Arqueológico Nacional y se fecha a fines del siglo III o comienzos del IV
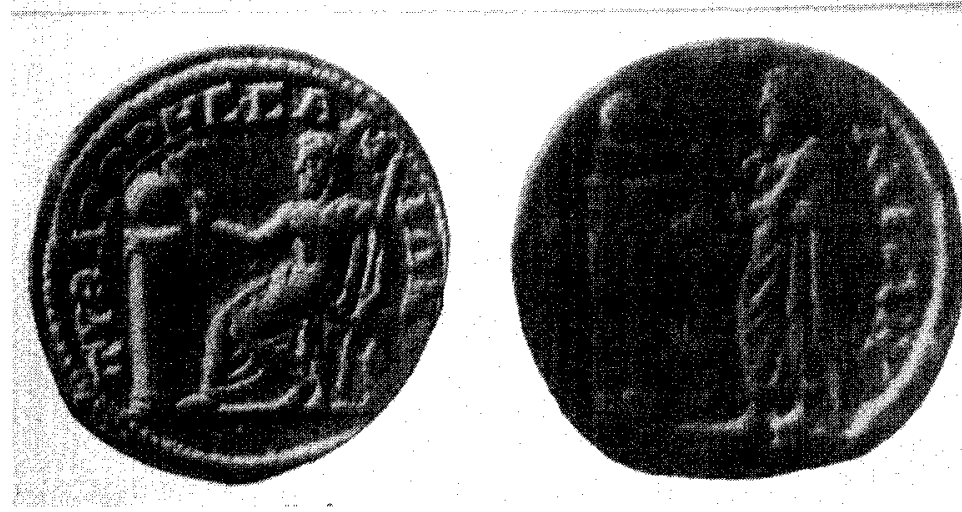

Figura 31. Monedas de Samos. Pitágoras.

82 G.M.A. RICHTER, The Portraits of the Greeks, London 1965, I, 79, figs. 302-303.

83 1. LOPEZ GARCÍA et alii, Hallazgos arqueológicos en el Palau de Les Corts, Valencia 1994, 142-156, 495-497, láms. 32-43. Agradezco al Prof. Dr. J. Gómez Pallarès el haberme facilitado la lectura de esta inscripción. 


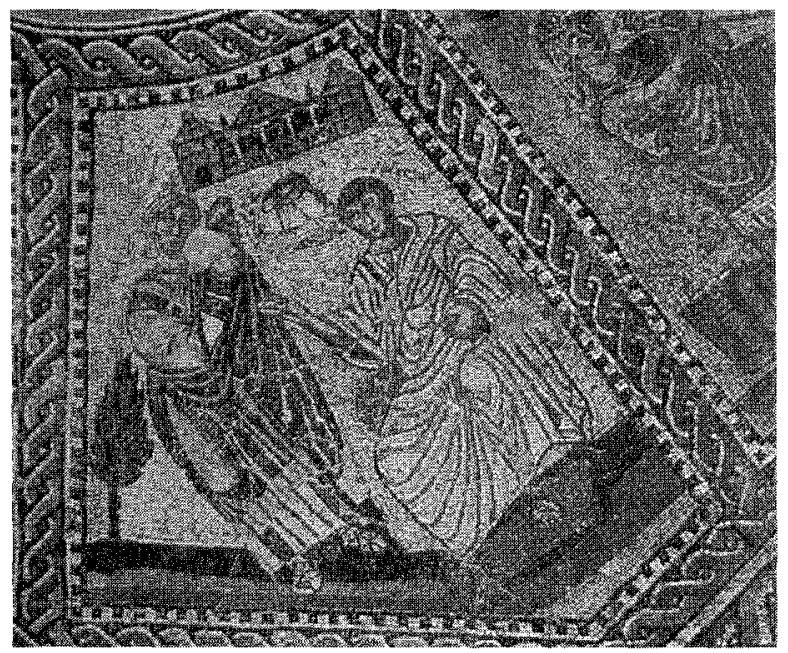

Figura 32. Mosaico de Arróniz. Compartimento IV.

d.C., presenta una composición octogonal dividida en nueve compartimentos, en cada uno de los cuales se ha representado un grupo integrado por un sophos, generalmente en posición sentada y una musa en pie delante de una villa. M. Hernández ha identificado con seguridad los grupos de Homero y Calíope en el sector I; Menandro (máximo representante de la comedia nueva) y Talía en el sector IV; Hiagnis (inventor del monoaulós que toca la musa) y Euterpe en el sector V; Cadmo (historiador o descubridor de la escritura fenicia) y Clío en el VI; Arato (poeta y astrónomo) y Urania portando la esfera y el radius en el IX ${ }^{84}$. J. Lancha, teniendo en cuenta las fotografías tomadas del mosaico antes de su restauración y traslado al Museo Arqueológico de Madrid, propone otras identificaciones para algunos de los grupos: Polimnia y un actor en el sector I; Terpsícore y orador en el II; Melpomene y Eurípides o Menandro en el III; Calíope y un orador o poeta en el VI; y tal vez Erato en el VIII ${ }^{85}$. J. Gómez Pallarès

84 J.M. BlázQUez-M.A. MEZquírIz, Mosaicos romanos de Navarra, CME VII, Madrid 1985, 1522.; M. HeRnÁndez IÑIGUEZ, Notas sobre el programa iconogrático del mosaico de las Musas y Maestros de Arróniz (Navarra), Actas de la / Mesa Redonda Hispano-Francesa sobre Mosaicos Romanos (Madrid 1985), Guadalajara 1989, 215 y ss. Otras identificaciones han sido propuestas por diversos autores.

85 J. LANCHA, La Mosaïque des Muses d'Arroniz (Navarre). Une approche du pavement originel et quelques hypothèses sur l'identification de certains personnages, La Mosaïque Gréco- 
ha identificado el texto escrito en el volumen que sostiene el sabio del sector VI, distinguiendo el nombre Cadmos en la segunda y tercera líneas, que identifica con seguridad al personaje representado ${ }^{86}$.

El conocido mosaico de Monnus de Trier, de la primera mitad del siglo III, conservado en el Rheinisches Landesmuseum, ofrece una complicada composición en donde están representados literatos, sabios y musas, todos acompañados de sus nombres escritos en latín. En el panel central se ha representado a Homero con Ingenium y Calíope, rodeados de ocho bustos dentro de recuadros que figuran a algunos de los más conocidos representantes de la literatura griega y latina: Hesíodo, Livio, Virgilio, Cicerón, Menandro y Ennius. En otros paneles están representados los sabios y las musas, en grupos de dos, aquellos por lo general sentados y en pie las musas. Se han conservado Melpomene; Thamyris; Polimnia e Icaros, éste con un libro enrollado en su mano; Urania y Aratos (Fig. 33), entre ambos un globo colocado sobre un trípode que el sabio enseña a la musa, escena muy similar a la representada en una copa de plata de la

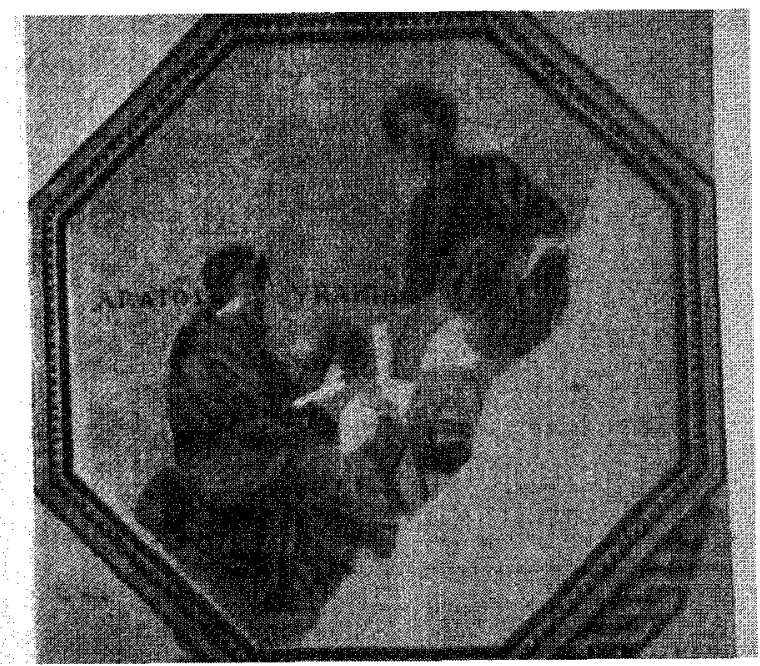

Figura. 33. Mosaico de Monnus de Trier. Aratos y Urania.

Romaine IV, Paris 1994, 302 y ss. Según la autora, el personaje identificado con Hiagnis en el sector $V$ responde perfectamente a la descripción que se hace en las fuentes literarias de este poeta, mientras que en el mosaico de Monnus de Trier, donde aparece identificado por su nombre, no presenta rasgos fisognómicos particulares.

${ }_{86}$ J. GómeZ PALLARĖs, Varia Musiva Epigraphica I-VII, Conimbriga XXX, 1991, 137-138. 
Biblioteca Nacional de Paris (Fig. 34) ${ }^{87}$ y que se repite en el códice astronómico de Arato (Madrid A.16) del siglo XII (Fig. 35), suponiendo BianchiBandinelli que debió existir un modelo helenístico común para ambas obras de arte y en este sentido la miniatura de Arato constituye un buen ejemplo de la perduración y difusión de los esquemas iconográficos antiguos en época medieval ${ }^{88}$; Cadmos y Clío, entre ellos una columna cuadrada que soporta una esfera (?); Euterpe y Hiagnis, es el cuadro mejor conservado y en él la musa está representada recibiendo las enseñanzas del maestro, que aparece en pie delante de una cathedra y a su izquierda la capsa con los volúmenes; y Talía ${ }^{89}$.

Una variante del grupo formado por un sabio en compañía de una musa se encuentra en el pavimento de Sousse (Fig. 36), procedente de la habitación 6 de la Casa de las Máscaras en Hadrumetum y conservado en el Museo de Sousse. En el emblema de forma circular se ha representado a dos personajes identificados como un poeta y un actor. El primero aparece sentado sobre un estrado en actidud pensativa, con una mano en la barbilla

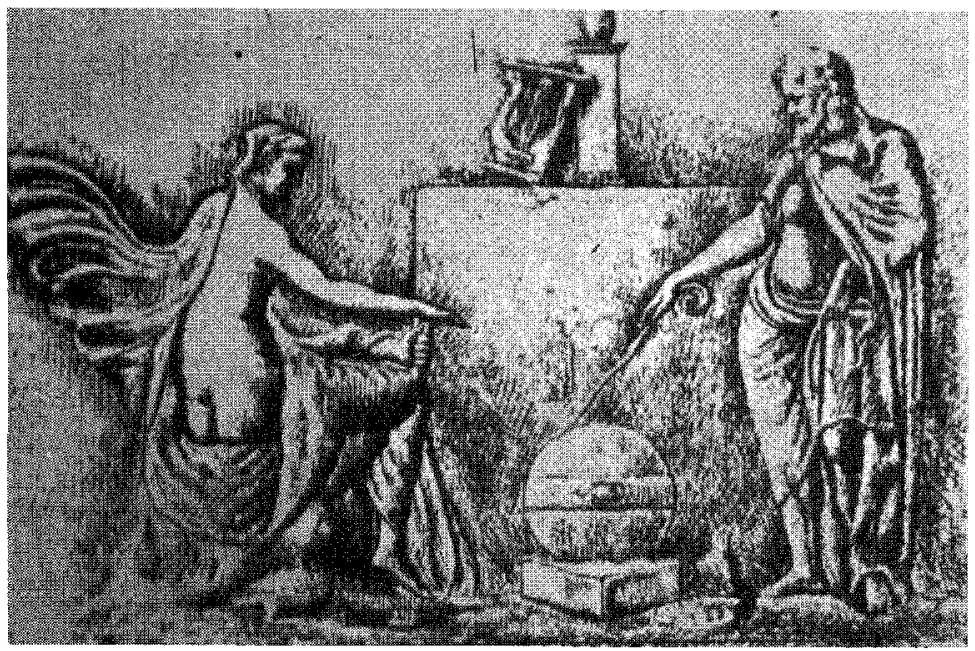

Figura 34. Copa de plata de la Biblioteca Nacional de París.

87 Cf. G.M.A. RichteR, The Portraits of the Greeks, London 1965, II, 240, Fig. 1660.

88 Cf. R. BIANCHI-BANDINELLI, Continuità ellenistica nella pittura di età medio e tardo-raomana, RINSA, 1953, 77 y SS.

89 K. PaRlasca, Die römischen Mosaiken in Deutschland, 1959, 41-43, Taff. 42-47; E. THEOPHILIDOU, Die Musenmosaiken der römischen Kaiserzeit, TZ 47, 1984, 280-286. 


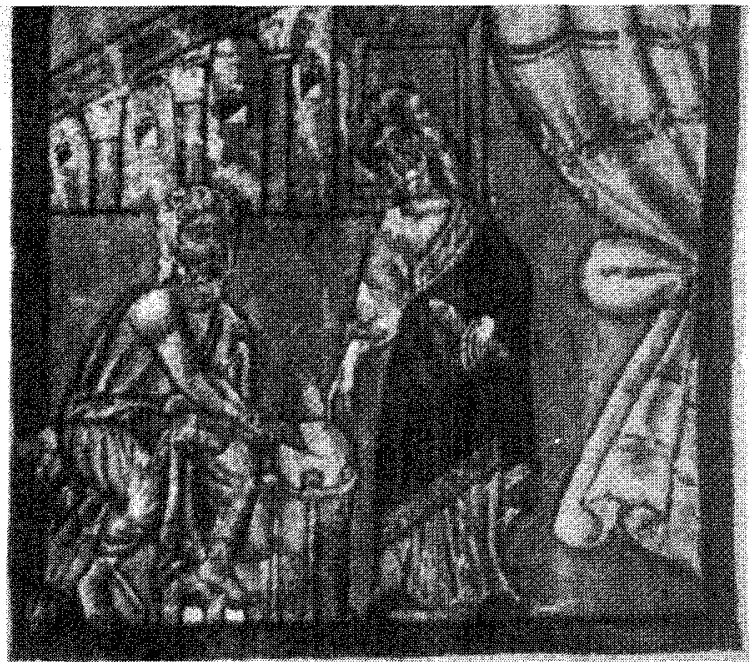

Figura 35. Códice astronómico de Arato (Madrid A.16).

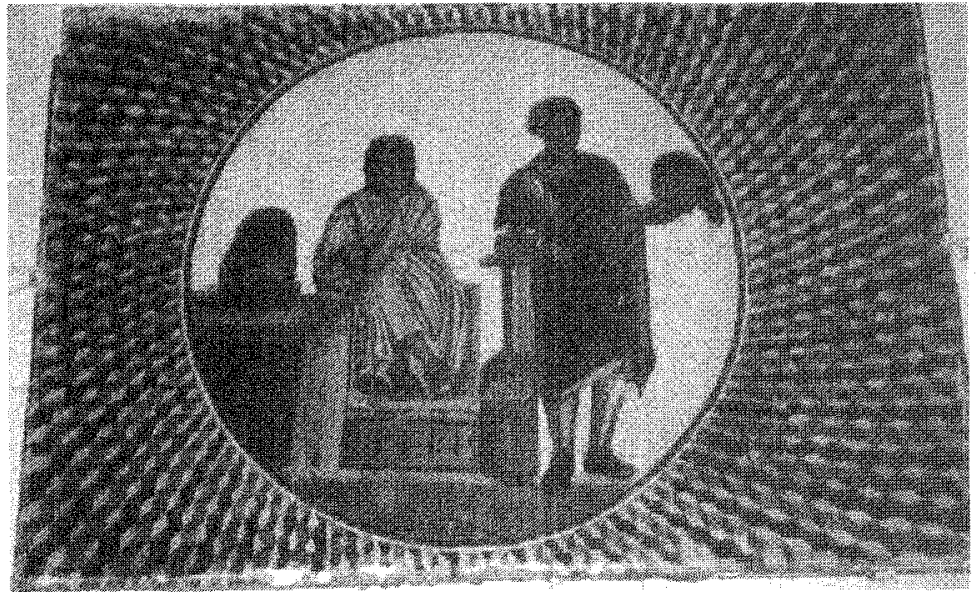

Figura 36. Mosaico de la Casa de las Máscaras de Sousse.

(Foto G. López Monteagudo).

y la otra sosteniendo un rollo. A la derecha del poeta y en un primer plano se ha representado una mesa, sobre la que hay una máscara trágica de gran tamaño; a la izquierda la capsa llena de volúmenes y un personaje en pie, probablemente un actor, que apoya el brazo derecho en un trípode y sostiene una máscara juvenil en la mano izquierda. El contenido del resto de 
los mosaicos de la casa ha hecho pensar en la sede de un collegium de actores o también en un propietario apasionado por el teatro. Se data en 220$230^{90}$.

Una posible representación de Menandro acompañado de tres actores y de una inscripción en griego con su nombre y el de su obra «Los aqueos", se encuentra en un pavimento de Oescus, en Bulgaria, datado en el primer cuarto del siglo III d.C., aunque también podría tratarse de una escena de su comedia ${ }^{91}$.

Al tipo de sabios representados como figuras individuales de cuerpo entero, por lo general sentados en cathedrae, en actitud reflexiva o declamatoria, pertenecen los mosaicos de Roma, Thuburbo Maius, Autun y Palermo.

De Roma se conoce un fragmento de mosaico polícromo (Fig. 37) hallado a comienzos del siglo XVIII en el Aventino de Roma y enviado por el

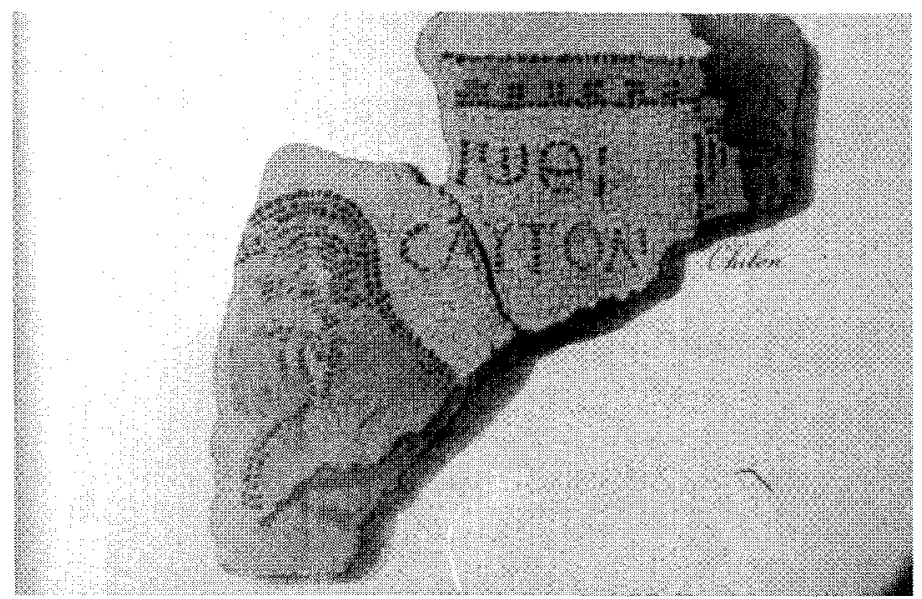

Figura 37. Mosaico del Aventino de Roma. Quilón.

90 L. Foucher, La Maison des Masques à Sousse, Tunis 1965; K.M.D. Dunbabin, The Mosaics of Roman North Africa, Oxford 1978, 131-132, 271. un precedente para esta escena se encuentra en el mosaico helenístico hallado en la casa del Poeta Trágico, en Pompeya, en donde seguramente se ha representado a Esquilo, cf. M. BIEBER, The history of the Greek and Roman Theater Princeton 1961,12 y 20 , figs. 36 y 62 .

91 T. IVAnov, Römische Mosaiken aus Colonia Ulpia Oescensium (Heute Bulgarien), CMGR IV, Paris 1994, 159-164, Taf. LXXXII,3. Representaciones de obras de Menandro se documentan en pavimentos de Mitilene (vid. supra). 
cardenal Bianchini a la Biblioteca Capitular de Verona, donde permaneció durante un siglo hasta que en el cambio del siglo XVIII al XIX fué regalado por Napoleón, perdiéndose su rastro en Francia. De él queda un dibujo a color en la Biblioteca Vaticana ${ }^{92}$. Solamente se conserva la parte superior de una figura masculina, con los hombros y el torso desnudos y la cabeza apoyada sobre la mano en actitud pensativa, postura que predomina en el tipo iconográfico del filósofo representado en el arte griego y helenístico ${ }^{93}$. A juzgar por la posición, similar a la del personaje situado en sexto lugar en el mosaico de Torre Annunziata (vid. supra), en el tunecino de Thuburbo Maius y en el de Autun (vid. infra), con los que también tiene de común la desnudez, y sobre todo con el retrato del sabio, identificado por su nombre "Quilón», en el citado fresco de Ostia de época hadrianea (Fig. 38) ${ }^{94}$, parece lógico suponer que el sabio se hallaba sentado e incluso es

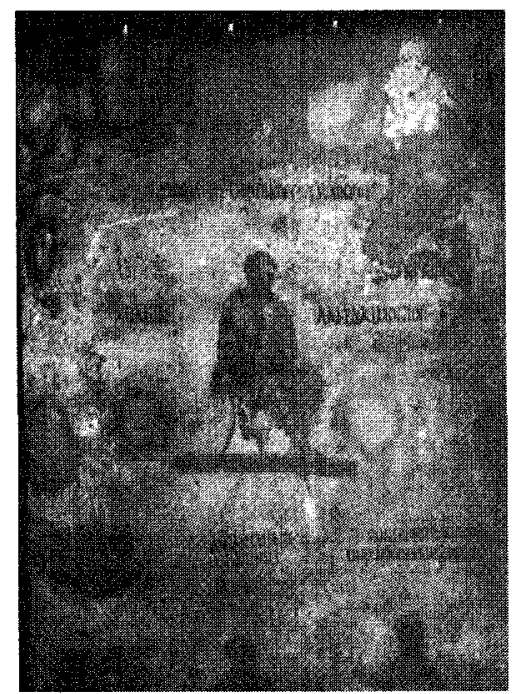

Figura 38. Fresco del «Palazzo dei Cesari» en Ostia. Quilón.

92 G. WINCKELMANN, Monumenti antichi iriediti, 1767, nำ165; E.Q. VISContı, Iconographie Grecque !, 1824, 159 y ss., PI. 11; J.J. BERNUILLI, Griechische Ikonographie 1, 1901, 51; S. REINACH, RPGR, Paris 1922, 262,4; M. DONDERER, Ein verschollenes römisches Mosaik und die Gattung der Wandemblemata, Mosaïque. Recueil d'hommages à H. Stern, Paris 1983, 123-128, PI. LXVI,1.

93 M. BIEBER, The Sculpture of the Hellenistic Age, New York 1961; G.M.A. RICHTER, The Portraits of the Greeks, London 1965.

94 G. Calza, Die Taverne der Sieben Weisen in Ostia, Die Antike 15, 1939, 101 y ss, fig. 3; G.M.A. RICHTER, The Portraits of the Greeks, London 1965, I, 91, Fig. 360. 
posible que formara parte de un grupo de sabios reunidos en simposion. A su espalda la inscripción en griego: «Conócete a tí mismo», máxima de Quilón de Esparta, permite identificarle con este filósofo. Probablemente otra inscripción, situada delante del personaje, indicaba su nombre, al igual que en los pavimentos de Mérida, Baalbeck, sala AB de Apamea y Nerodimjle. M. Donderer fecha este pavimento, por el marco dentado, en el siglo II d.C.

El mismo tipo iconográfico se documenta en el mosaico de Thuburbo Maius, conservado en el Museo de El Bardo y datado en el tercer cuarto del siglo II. En el panel central (Fig. 39) se muestra a un personaje sentado sobre un trozo de columna, con paralelos en pinturas pompeyanas ${ }^{95}$; se halla en actitud pensativa, con la barbilla sobre la mano derecha y un rollo desplegado en la izquierda que parece estar leyendo; adorna la cabeza con una corona vegetal y va vestido con amplio ropaje que cubre el hombro derecho y cae sobre la espalda dejando al descubierto el torso; delante de él se sitúa una mesa con dos máscaras de la comedia. Se le ha identificado como un poeta, tal vez Menandro o Ennius ${ }^{96}$. El tipo iconográfico re-

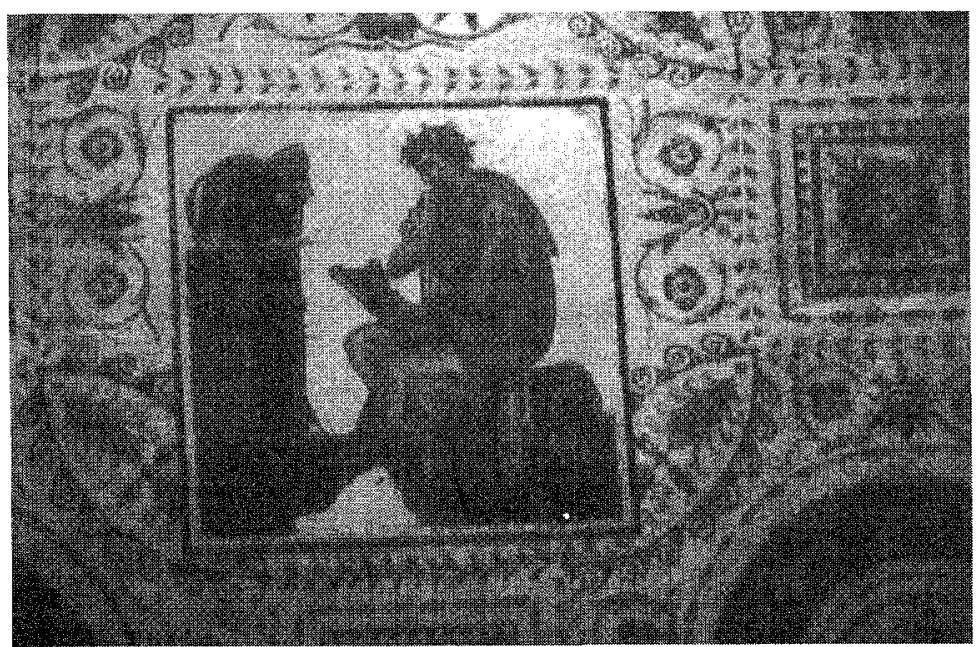

Figura 39. Mosaico de Thuburbo Maius. Emblema. (Foto G. López Monteagudo).

95 Escenas representando a Ulises y Penélope, y pintora, cf. S. REINACH, RPGR, Paris 1922, $175,2-3$ y 262,8 .

96 K.M.D. Dunbabin, The Mosaics of Roman North Africa, Oxford 1978, 132, 274. 
cuerda al de Quilón en el fragmento procedente del Aventino de Roma (vid. supra), y al de Metrodoro del panel de Autun (vid. infra), datados también en el siglo II; los personajes están representados a la manera de los filósofos, en actitud reflexiva, van semidesnudos, revestidos solamente de un simple pallium, atributo de los cínicos y de los filósofos en general, por lo que es posible que el modelo para todos ellos hubiera sido el mismo.

Gran interés iconográfico ofrecen los personajes representados en el mosaico de Autun, que se conserva en el Museo Rolin de la ciudad. El pavimento, que procede de una gran sala central terminada en ábside y se fecha, por criterios filológicos, a fines del siglo II d.C., presenta una composición formada por meandros de esvásticas y cinco cuadrados, cada uno de los cuales va decorado con un personaje masculino, de cuerpo entero, sentado en un sillón y acompañado de un texto literario ${ }^{97}$.

En uno de los paneles (Fig. 40) se ha figurado a un poeta lírico sentado en el borde de una silla de espalda curva; viste pallium que descubre el hombro derecho y toca con las dos manos las cinco cuerdas de la lira; lleva barba, cabellos largos y abundantes y tiene una mirada vigorosa $e$

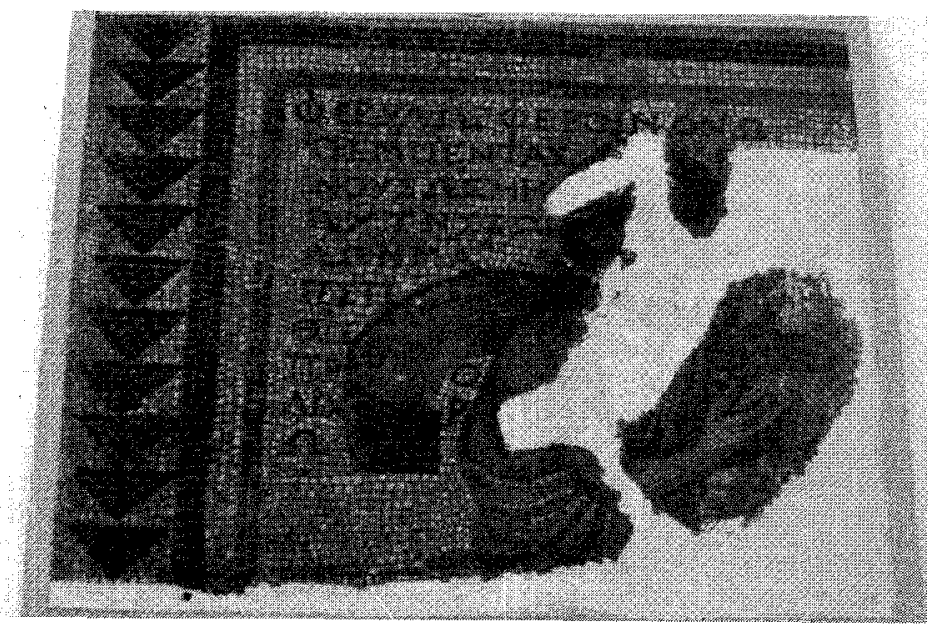

Figura 40. Panel del mosaico de Autun. (Foto G. López Monteagudo).

97 M. BLANChard - A. Blanchard, La mosaïque d'Anacréon à Autun, REA LXXV, 1973, 268279; RGMG II.2, Paris 1975, 59-60, $\mathrm{n}^{\circ}$ 213; A. BLANCHARD, Epicure, "Sentence Vaticane" 14 : Epicure ou Métrodore?, REG 104, 1991, 394-409; Id., Epicure dans une anthologie sur mosaïque à Autun, CRAI, 1993, 969-984. 
inspirada. Sigue el tipo iconográfico del poeta lírico sentado, creado quizás en el siglo $V$ a.C. para representar a Píndaro y retomado en época helenística, del que es un ejemplo la escultura de Píndaro del Serapeion de Menfis, datado a comienzos del siglo III a.C. El tipo de sillón de espalda curvada (cathedra) se documenta igualmente en los mosaicos de Trier, Virgilio de Sousse, Monnus (vid. supra) y Palermo (vid. infra). Aunque no hay rótulo con el nombre, parece que el personaje puede identificarse con Anacreonte, ya que toda la mitad superior del cuadro estaba ocupada por una inscripción griega, datable a fines del siglo II d.C., correspondiente a la Antología de Anacreonte (Poemas Anacreónticos), que hace alusión a Anacreonte como poeta del vino, de la guerra y del amor.

En el otro panel se ha representado a Metrodoro sentado también en una cathedra, como hombre de edad madura, calvo y barbado, vestido con pallium y sandalias; apoya la barbilla en la mano derecha, en actitud pensativa, y sostiene un volumen en la mano izquierda; va rodeado por la "Sentencia Vaticana" 14 atribuida a Epicuro y el nombre completo del filósofo en la parte baja del cuadro no deja lugar a dudas sobre su identificación como Metrodoro. Iconográficamente pertenece al tipo de sabio sentado en actitud reflexiva, documentado en los mosaicos de Torre Annunziata, Roma y Thuburbo Maius también del siglo II, así como en el de Sousse con la representación de poeta y actor, que se fecha en el primer cuarto del siglo III (vid. supra).

Un tercer panel representa a Epicuro, identificado por su nombre, como un personaje masculino de edad madura, barbado y vestido con el pallium; está sentado no en un klismos como Anacreonte y Metrodoro, sino en un trono con patas de león; la mano izquierda ofrece un gesto de discusión, como los personajes del mosaico de los «literatos» de Trier, mientras que levanta el brazo derecho blandiendo un bastón curvo. La inscripción que le acompaña ha sido identificada con la «máxima capital» $V$ de Epicuro (Diog. Laert. X 132).

En la parte inferior del mosaico descubierto en la Casa A de la plaza de la Victoria, en Palermo, decorado con diversas escenas mitológicas, se han representado dentro de octógonos tres personajes masculinos, sentados en sillones de alto respaldo curvo (cathedrae) junto a unas mesas sobre las que están depositados varios rollos. Van vestidos con el pallium de los filósofos y su actitud es de meditación. D. Levi los identifica con tres sabios de la Antigüedad, Eurípides, Homero y Pitágoras; sin embargo, la presencia de máscaras de la tragedia lleva a pensar en su identificación como escritores 
o autores. D. Boeselager fecha este mosaico en la primera mitad del siglo III d.C. ${ }^{98}$.

La vida intelectual aparece reflejada figualmente en tres de los paneles del enigmático mosaico de los caballos de Cartago. El pavimento, que se conserva in situ en el oecus de la Casa de los Caballos y se fecha en 300-320, está formado por paneles cuadrados con las imágenes de caballos de circo acompañados de personajes o de escenas que, según J.W. Salomonson, harían alusión a sus nombres ${ }^{99}$.

En el cuadro 5 se ha representado a un personaje masculino en pie vestido con pallium y sosteniendo con ambas manos un volumen; en la parte de atrás de la derecha dos máscaras del teatro, colocadas sobre un estrado, hacen alusión a la personalidad del personaje, tal vez un autor o poeta cómico que bien podría ser Menandro. El caballo lleva sobre el anca una marca en forma de serpiente y su nombre podría ser, siguiendo a J.W. Salomonson, Menandro, Apuleyo o Roscio, que se encuentran documentados como nombres de caballos en otros soportes ${ }^{100}$.

El cuadro 7 (Fig. 41) muestra a un personaje masculino vestido con túnica corta, decorada con clavi, orbiculi y segmenta, y manto sobre sus

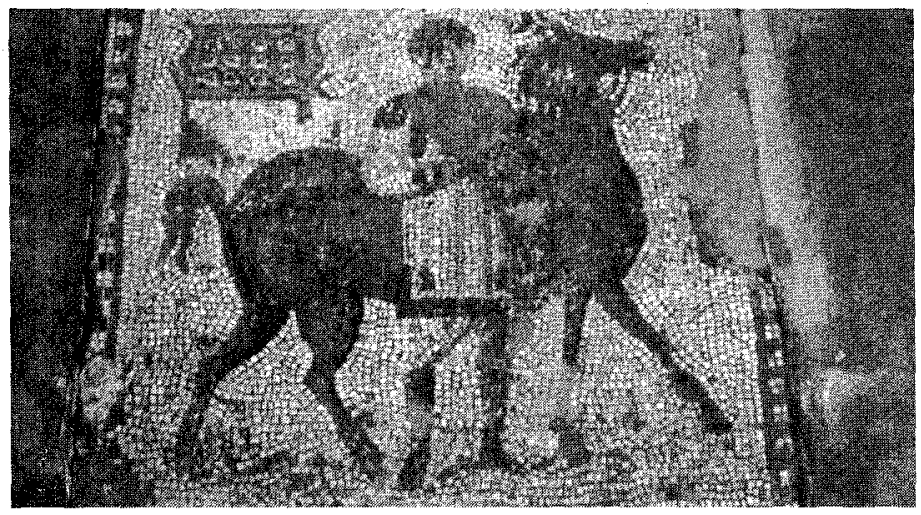

Foto 41. Mosaico de la Casa de los Caballos de Cartago, cuadro 7. (Foio G. López Monteagudo).

98 D. LEVI, Mors voluntaria, Berytus VII, 1942, 40, pl, 5; D. von Boesel.AGer, Antike Mosaiken in Sizilien, Roma 1983, 176-183, Abb. 123.

99 J.W. SALOMONSON, La mosaïque aux chevaux de l'antiquarium de Carthage, La Haye 1965, 74-75, 80-89; K.M.D. DunbaBin, The Mosaics of Roman North Africa, Oxford 1978, 95-96.

100 A. Audollent, Defixionum Tabellae, Paris 1904, núms. 159, 160; J.M.C. ToYnBeE, Beast and their names in the Roman Empire, PBSR 16, 1948, 29. 
espaldas. Peina el cabello corto hacia adelante y sostiene en sus manos un objeto que no se ha conservado, tal vez un libro o rollo. A la izquierda y detrás del caballo, se ha representado lo que parece ser la «biblioteca» Ilena de volumina, a juzgar por los paralelos documentados en sarcófagos de la misma fecha ${ }^{101}$. Sobre el anca del caballo se lee con toda claridad SAP.

Más interés ofrece el cuadro 50 (Fig. 42) donde aparece un hombre barbudo, vestido con el pallium de los intelectuales, que levanta la cabeza hacia arriba en actitud declamatoria; sostiene en sus manos un rollo desplegado en el que se aprecian caracteres griegos en dos líneas superpuestas, que J. Gómez Pallarès ha leído en escritura bustropédica como Tales de Mileto, lo que identifica de forma segura al personaje representado, aunque la iconografía no coincide con la conocida de este personaje, sino que sigue más la utilizada para representar a literatos, como ocurre con Virgilio del mosaico de Sousse y con Cadmos del pavimento de Arróniz (vid. supra) ${ }^{102}$.

En otros mosaicos se representan escenas de difícil interpretación, como ocurre con el pavimento de Lamberidi, conservado en el Museo de

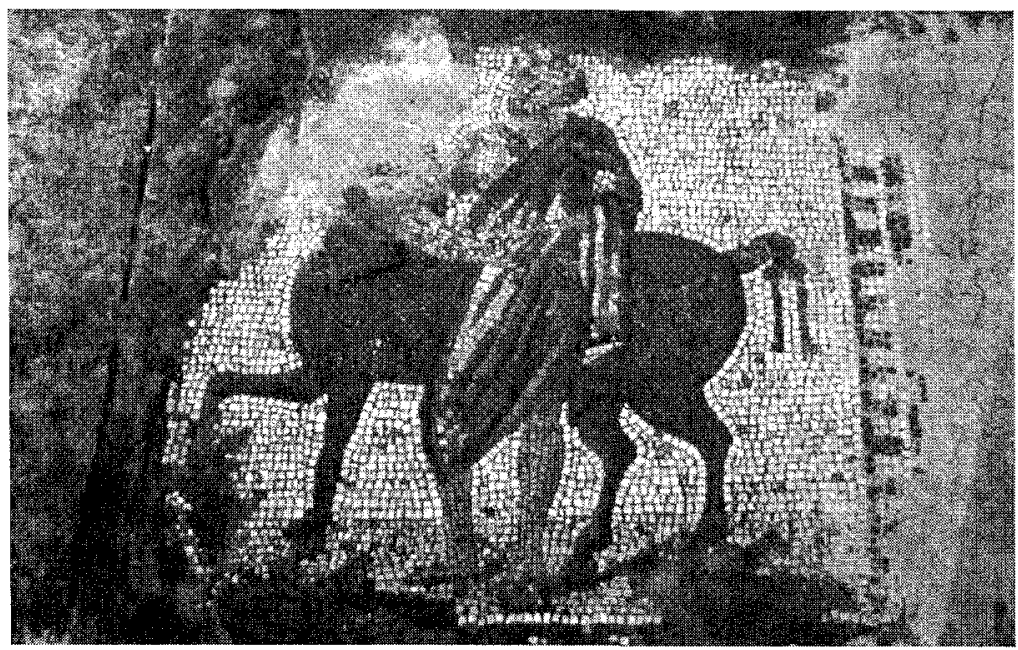

Figura 42. Mosaico de la Casa de los Caballos de Cartago, cuadro 50.

(Foto G. López Monteagudo).

101 M. Simon, La civilisation de l'antiquité et le christianisme, Paris 1972, 200, fig. 72.

102 Agradezco al Prof. Dr. J. Gómez Pallarès el haberme proporcionado la lectura del texto escrito. 
Argel procedente de la tumba de Cornelia Urbanilla, datado a comienzos del siglo IV. En el medallón central se representa una escena en la que intervienen dos personajes masculinos sentados en sendas banquetas de patas torneadas (sella). Uno, de edad madura, con barba y vestido con himation, que sigue el modelo clásico utilizado en los retratos de Hipócrates y que recuerda muy de cerca a la figura de Hipócrates representada en moneda de Cos del siglo I d.C. ${ }^{103}$, parece auscultar al jóven desnudo sentado en frente de él. F. Chamoux interpreta la escena como la historia de Perdiccas e Hipócrates, mientras que J. Carcopino, basándose en las inscripciones del mosaico y en la presencia del sarcófago en el interior de la tumba, opina que todos los motivos del mosaico, determinados por doctrinas hermetísticas, se han escogido para expresar ideas de una secta filosófico-religiosa ${ }^{104}$.

Más raro es que los sabios o filósofos aparezcan formando parte de una historia, como la figura de Hipócrates en el mosaico de la casa de Esculapio de Cos, fechado a fines del siglo 11 o comienzos del III y conservado en el castillo de Rodas, en donde se ha escenificado la epiphanía de Asclepios a su llegada a la isla ${ }^{105}$. En la escena intervienen tres personajes: el dios desciende de la barca y es acogido con sorpresa y admiración por un viandante; al otro lado aparece Hipócrates sentado en una roca y vestido a la manera de los docentes. El prototipo iconográfico del filósofo sedente se encuentra en el arte helenístico y concretamente en el citado serapeion de Menfis.

A través de estas representaciones musivarias se puede ver cómo los tipos iconográficos varian de unas zonas a otras del imperio: el grupo de los siete sabios reunidos en simposion se documenta en los pavimentos de Italia, de Hispania y del Oriente, existiendo variantes en Germania y Yugoslavia; los sabios acompañados del intrumento científico son privativos de Britania y Germania; por el contrario, los intelectuales solos o junto a las musas, en forma de busto o de cuerpo entero, es un tema extendido por todo el imperio; y por supuesto también se documentan unica, como es el caso de las escenas representadas en

103 G.M.A. Richten, The Portraits of the Greeks, London 1965, 1, 151-154, Figs. 855 874. Sobre el tipo de banqueta (se//a) derivada del diphros griego cf. G.M.A. RicHTER, Ancient Furniture, Oxford 1926, 30-38, 125-126.

104 J. Carcopino, Aspects mystiques de la Rome païenne, Paris 1942, 207-313; F. Chamoux, Perdiccas, Hommages à A. Grenier, I, Coll. Latomus 58, 1962, 388-394; K.M.D. DunBABIN, The Mosaics of Roman North Africa, Oxford 1978, 139-140, 264.

105 M.L. MorRicone, Scavi e ricerche a Coo (1935-1943. Relaziones preliminare) BollArte 35, 1950, 317; Hellenika 26, 1973, 232, nº 24, pl. 14. 
los mosaicos de Lamberidi, de Cos o de Sousse. No obstante, todas ellas reflejan en parte la vida intelectual romana, ya que además de los retratos de los hombres de ciencia, hay otras formas de hacer referencia a la cultura y sobre todo a la sabiduría como concepto abstracto, mediante representaciones alegóricas en forma humana o también con escenas, en su mayor parte mitológicas, provistas de códigos de lectura de contenido filosófico.

En el grupo de las representaciones abstractas destacan las figuras alegóricas del concepto filosófico de la sabiduría o de la ciencia en general ${ }^{106}$; imágenes emanadas de las obras de los poetas o fuente de inspiración de las mismas ${ }^{107}$; y aquellas escenas sacadas del repertorio mitológico pero cuyo contenido está en función de la sabiduría. Entre estas últimas hay que destacar la figura de Ulises que para los antiguos encarnaba la imagen de sabio, de personaje ejemplar propuesto por las diferentes sectas filosóficas como modelo para sus adeptos: ideal de virtud para los cínicos y de fortaleza para los estóicos, era también el sabio platónico por excelencia ${ }^{108}$. Sirva como ejemplo de este grupo el mosaico de Ulises y las Terapénides procedente de Apamea, conservado en los Museos Reales de Arte y de Historia de Bruselas.

Podría hacerse un grupo mixto en el que los retratos de los sabios, acompañados a veces de las musas, dispuestos alrededor del cuadro principal, confieren un carácter filosófico a la escena mitológica cuyo contenido también se halla conectado con el concepto abstracto de la ciencia o de la sabiduría. Este sería el caso del citado mosaico báquico de Gerasa y, a nuestro parecer, del pavimento hispano de La Olmeda (Pedrosa de la Vega, Palencia), donde los bustos de la orla podrían ser representaciones de sabios y musas, a través de retratos de personajes de la época, en relación con la lectura en clave filosófica del cuadro: el triunfo de la sabiduría encarnada por Ulises sobre la astucia de Aquiles.

106 La personificación de la Sophía fué muy frecuente en el mundo clásico, de donde pasó al pensamiento y al arte bizantinos como símbolo de la sabiduría de Dios.

107 L. FOUCHER, L'art de la mosaïque et les poètes latines, Latomus XXIII, 1964, 247 y ss.

108 En la exégesis mística de Numenius de Apamea y de los neoplatónicos, Ulises simbolizaba el alma exilada en la materia, de la que se libera a través del ejercicio de la sophía y de la inteligencia y alcanza la inmortalidad (Porph. de antro nymph. 34); en Plotino (Enn. V 9.1) la llegada del héroe homérico a ttaca representa la imagen del sabio que, liberado del mundo de la materia accede al plano espiritual que es el verdadero medio de su alma, "como un hombre que llega, después de un largo vagar, al bello país civilizado de sus padres». Todo este simbolismo de la figura de Ulises en relación con la doctrina neoplatónica del alma pasa al cristianismo ya a fines del siglo 11 , como modelo del cristiano perfecto cuya única aspiración es el reecuentro con Dios en la patria celeste, sinónimo de Itaca (Clem. Alex. Protrept. X 109,1; XII 118, 1-4), cf. J. BALTY, Iconographie et réaction païenne, Mélanges $P$. Lévêque I, Paris 1988, 17 y ss. 
En todos estos casos y cuando no hay inscripción identificatoria es dificil distinguir entre filósofos y literatos ya que, como dice H.I. Marrou refiriéndose a los sarcófagos, los argumentos esgrimidos para la identificación son muy débiles: la semidesnudez de los personajes revestidos de un simple pallium es un atributo de los cínicos y de los filósofos en general, pero también puede ser un símbolo de heroización; el reloj de sol induce a pensar en estudios astronómicos y matemáticos, pero también puede ser un reloj simbólico que marca la hora del destino; algunos atributos de las Musas, como la lira o las máscaras, evocan la poesía lírica y el arte dramático, esto es la cultura literaria, pero también pueden hacer alusión a la ciencia en general ${ }^{109}$. No obstante, todos ellos reflejan aspectos de la vida intelectual y contribuyen, junto a otro tipo de fuentes, al mejor conocimiento de la sociedad romana.

109 H.I. MARROU, MOYCIKOC ANHP. Etude sur les scènes de la vie intellectuelle figurant sur les monuments funéraires romaines, Roma 1964,218 y ss. 